\title{
Incidence and prognosis of dysnatraemia in critically ill patients: analysis of a large prevalence study
}

Frédéric Vandergheynst*, Yasser Sakr ${ }^{\dagger}$, Peter Felleiter ${ }^{\ddagger}$, Rudolf Hering ${ }^{\S}$, Johan Groeneveld ${ }^{\Uparrow}$, Philippe Vanhems**, ${ }^{* \dagger}$, Fabio S. Taccone ${ }^{\ddagger \ddagger}$ and Jean-Louis Vincent ${ }^{\ddagger \ddagger}$

*Department of General Internal Medicine, Erasme Hospital, Université libre de Bruxelles, Brussels, Belgium, ${ }^{\dagger}$ Department of Anesthesiology and Intensive Care, Friedrich-Schiller University, Jena, Germany, ${ }^{\ddagger}$ Department of Intensive Care, Swiss Paraplegic centre, Nottwil, Switzerland, ${ }^{\S}$ Department of Anesthesiology and Intensive Care Medicine, Kreiskrankenhaus Mechernich and University of Bonn, Mechernich, Germany, "Department of Intensive Care, Erasmus Medical Center, Rotterdam, The Netherlands, **Service d'Hygiène, Epidémiologie et Prévention, Hospices Civils de Lyon, Hôpital Edouard Herriot, Université de Lyon, Lyon, France, ${ }^{+\dagger}$ Laboratoire de Biométrie et de Biologie Evolutive, Equipe Epidémiologie et Santé Publique, CNRS UMR 5558, Lyon, France, ${ }^{\neq \neq}$Department of Intensive Care, Erasme Hospital, Université Libre de Bruxelles, Brussels, Belgium

\begin{abstract}
Background The objective of this study is to assess the impact of dysnatraemia on mortality among intensive care unit (ICU) patients in a large, international cohort.

Material and methods Analysis of the Extended Prevalence of Infection in Intensive Care (EPIC II) study, a 1-day (8 May 2007) worldwide multicenter, prospective point prevalence study. Hyponatraemia was categorized as mild (130-134 mM/L), moderate (125-129 mM/L) or severe $(<125 \mathrm{mM} / \mathrm{L})$. Hypernatraemia was also categorized as mild (146-150 mM/L), moderate (151-155 mM/L) or severe (> $155 \mathrm{mM} / \mathrm{L})$. Patients with normal serum sodium (135-145 mM/L) constituted the reference group. The main outcome was hospital mortality. Analysis was conducted separately for patients admitted on the study day (25.8\%) and those already present on the ICU (74.2\%).

Results Serum sodium was measured in 13276 of the 13796 patients (96.2\%). A total of 3815 patients $(28.7 \%)$ had dysnatraemia: $12.9 \%$ with hyponatraemia and $15.8 \%$ with hypernatraemia. The prevalence of dysnatraemia was significantly greater in patients already present on the ICU prior to the study day than for those just admitted $(13.1 \%$ vs. $12.3 \%$ for hyponatraemia and $17.1 \%$ vs. $12.1 \%$ for hypernatraemia, both $P<0.001)$. Hospital mortality rates were higher in patients with dysnatraemia than in those with normal sodium levels and were directly related to the severity of hypo- and hypernatraemia. This association between dysnatraemia and mortality was similar in infected and noninfected patients $(P=0.061)$.
\end{abstract}

Conclusions Dysnatraemia is more frequent during the ICU stay than on the day of admission. Dysnatraemia in the ICU - even mild - is an independent predictor of increased hospital mortality.

Keywords Hypernatraemia, hyponatraemia, intensive care, propensity score, sodium.

Eur J Clin Invest 2013; 43 (9): 933-948

\section{Introduction}

Serum sodium measurements are obtained routinely in intensive care unit (ICU) patients. Dysnatraemia (hyponatraemia and hypernatraemia) is common in these patients and has prognostic implications, such that sodium levels have been integrated into several severity scores [1]. Hyponatraemia is associated with worse outcomes, particularly in patients with congestive heart failure [2] and cirrhosis [3]. In a retrospective database of more than 150000 ICU patients, Funk et al. [4] demonstrated that both hypo- and hypernatraemia present on admission to the ICU were independent risk factors for increased mortality. Patients were stratified into subgroups of hypo- and hypernatraemia (borderline, mild and severe), and even borderline dysnatraemia at admission to the ICU was an independent risk factor for poor prognosis. Recently, Whelan et al. [5] showed, in a cohort of more than 14000 acute unselected (emergency) general medical patients, that serum sodium at admission was a risk factor for in-hospital mortality. Again, even borderline hyponatraemia (130-134 mM/L) was 
associated with a worse hospital outcome. Waikar et al. [6] also stratified a large population of unselected hospitalized adult patients according to the degree of hyponatraemia and showed a close relationship between hyponatraemia - even mild - and mortality. A limitation of their study was the evaluation of a cohort of patients over a 10-year period, during which significant changes in diagnosis and therapy may have occurred. In a prospective study conducted over a 14-year period, Darmon et al. [7] also observed that dysnatraemia was an independent risk factor for day-30 mortality. In a study of ICU-acquired dysnatraemia, Stelfox et al. [8] showed that ICUacquired hypo- and hypernatraemia were associated with increased hospital mortality, but these authors did not evaluate the relationship between the severity of the dysnatraemia and outcome.

We, therefore, used a large prospective database of ICU patients [9] to evaluate whether dysnatraemia is an independent risk factor for increased mortality in critically ill patients. We also investigated whether the presence of infection in these patients and the occurrence of dysnatraemia at ICU admission or during the ICU stay impacted on outcomes.

\section{Patients and methods}

\section{Patient selection/database}

The Extended Prevalence of Infection in Intensive Care (EPIC) II study protocol has been reported in detail previously [9]. ICUs were asked to participate in a 1-day, prospective, multicenter point prevalence study, conducted to provide an upto-date picture of the extent and pattern of infection in ICUs throughout the world (see Appendix A for list of participating ICUs). Demographic, physiological and therapeutic data were collected from all patients between midnight on May 7 and midnight on 8 May 2007. The Simplified Acute Physiology Score (SAPS) II was calculated on the study day. Data were recorded using preprinted case report forms. Participating ICUs were asked to provide patient follow-up until discharge or for 60 days (until 9 July 2007), and ICU and hospital outcomes were recorded. Participation in the EPIC II study was entirely voluntary, and the study was not funded. For the original EPIC II protocol, local ethical committee approval at each participating centre was expedited or waived owing to the purely observational nature of the study.

\section{Definition of categories of patients}

As part of SAPS II, serum sodium was measured in every patient on the study day (8 May 2007); in $25.8 \%$ of the patients, this represented the day of ICU admission, and the remaining $74.2 \%$ of patients were already being treated in the ICU. We analysed these subgroups of patients separately. Patients with normal sodium (135-145 mM/L) values represented the refer- ence group. Dysnatraemia was divided into hyponatraemia (severe $<125 \mathrm{mM} / \mathrm{L}$, moderate $125-129 \mathrm{mM} / \mathrm{L}$ and mild 130-134 mM/L) and hypernatraemia (mild 146-150 mM/L, moderate 151-155 mM/L and severe $>155 \mathrm{mM} / \mathrm{L}$ ). The cutoffs used to divide dysnatraemia into categories were based on those previously used in the literature in order to be able to compare our results with previous reports $[4,6,7]$.

Infection was defined according to the definitions of the International Sepsis Forum [10] and adjudicated by the attending physician.

\section{Statistical analysis}

Statistical analyses were performed using IBM ${ }^{\circledR}$ SPSS $^{\circledR}$ Statistics 20 for Windows (IBM, Armonk, NY, USA). The KolmogorovSmirnov test was used, and histograms and normal quantile plots were examined to verify whether there were significant deviations from the normality assumption of continuous variables. Different testing between groups was performed using analysis of variance, Kruskal-Wallis, Student's t-test, MannWhitney U-test, chi-square test or Fisher's exact test as appropriate. The Bonferroni correction was made for multiple comparisons. Logistic regression analyses with hospital mortality as the dependent variable were performed to determine the mortality risk linked to dysnatraemia. To remove any bias of confounding variables for the association between dysnatraemia and mortality, a propensity score for each dysnatraemia class was estimated using multinomial logistic regression. The following variables were considered as factors: type of admission, source of admission, comorbidities, age, sex, mechanical ventilation, haemofiltration or haemodialysis, infection, SAPS II score and type of microorganism. After checking that balance on all covariates that were used in the propensity model had been achieved, we introduced the propensity score into the logistic regression model [11,12]. Reported odds ratios were adjusted for propensity score, hospital and organizational related factors, including type of ICU (closed vs. open, community vs. university, surgical vs. medical), number of ICU beds, number of nurses, number of physiotherapists, presence of 24-h ICU physician coverage, length of ICU stay prior to study day and geographical region. Data are presented as mean (95\% confidence interval), median [interquartile range (IQR)] or number (\%) as appropriate. All tests were two tailed, and a $P<0.05$ was considered statistically significant.

\section{Results}

\section{Characteristics of the study group}

The EPIC II study included 1265 ICUs in 76 countries with 13796 adult patients; 7087 (51.4\%) were infected. On the study day, serum sodium was measured in 13276 (96.2\%) of the patients. Of these measurements, $9461(71 \cdot 3 \%)$ were within the 
Table 1 Baseline patient characteristics and outcomes according to serum sodium level

$\begin{array}{lllllll}\mathrm{Na}<125 & 125<\mathrm{Na} \leq 129 & 130<\mathrm{Na} \leq 134 & \text { Na normal } & 146<\mathrm{Na} \leq 150 & 151<\mathrm{Na} & \mathrm{Na}>155 \\ \mathrm{mM} / \mathrm{L} & \mathrm{mM} / \mathrm{L} & \mathrm{mM} / \mathrm{L} & (135-145 \mathrm{mM} / \mathrm{L}) & \mathrm{mM} / \mathrm{L} & \leq 155 \mathrm{mM} / \mathrm{L} & \mathrm{mM} / \mathrm{L} \\ n=101 & n=253 & n=1359 & n=9461 & n=1411 & n=446 & n=245\end{array}$

Patient characteristics

\begin{tabular}{|c|c|c|c|c|c|c|c|}
\hline \multicolumn{8}{|l|}{ Age } \\
\hline Mean & 58.6 & 61.6 & $60 \cdot 1$ & $60 \cdot 7$ & $61.9 *$ & $60 \cdot 9$ & 58.6 \\
\hline $95 \% \mathrm{Cl}$ & $55 \cdot 4-61.9$ & $59.5-63.7$ & $59 \cdot 1-61$ & $60 \cdot 3-61$ & $61 \cdot 1-62 \cdot 8$ & $59 \cdot 3-62 \cdot 4$ & $56 \cdot 3-60 \cdot 9$ \\
\hline \multicolumn{8}{|l|}{ Male } \\
\hline$\%$ & $59 \cdot 4$ & 58.9 & $62 \cdot 1$ & 62.5 & $62 \cdot 4$ & 60.9 & $66 \cdot 5$ \\
\hline \multicolumn{8}{|l|}{ SAPS II } \\
\hline Mean & $48.4^{*}$ & $38.6^{*}$ & $35 \cdot 6^{*}$ & 33.9 & $41 \cdot 2^{*}$ & $45^{*}$ & $45 \cdot 9 *$ \\
\hline $95 \% \mathrm{Cl}$ & $44 \cdot 7-52$ & $36 \cdot 5-40 \cdot 6$ & $34 \cdot 7-36 \cdot 4$ & $33 \cdot 6-34 \cdot 2$ & $40 \cdot 4-42$ & $43 \cdot 4-46 \cdot 5$ & $43 \cdot 8-48$ \\
\hline \multicolumn{8}{|l|}{ SOFA } \\
\hline Mean & $8.5^{*}$ & $7 \cdot 2^{*}$ & $6 \cdot 3^{*}$ & 5.9 & $7.5^{*}$ & $8.5^{*}$ & $8.9 *$ \\
\hline $95 \% \mathrm{Cl}$ & $6 \cdot 9-10$ & $6 \cdot 5-7 \cdot 8$ & $6-6 \cdot 6$ & $5 \cdot 8-6$ & $7 \cdot 3-7 \cdot 8$ & $8-8.9$ & $8 \cdot 4-9.5$ \\
\hline \multicolumn{8}{|l|}{ Days in ICU } \\
\hline Median & 1 & 2 & $5^{*}$ & 2 & $4^{*}$ & $6^{*}$ & $6^{*}$ \\
\hline $\begin{array}{l}25-75 \text { th } \\
\text { percentile }\end{array}$ & $0-5$ & $0-11$ & $1-14$ & $0-9$ & $1-12$ & $1-13$ & $2-13$ \\
\hline \multicolumn{8}{|c|}{ Comorbid conditions } \\
\hline COPD & $10(9.9)$ & $42(16.6)$ & $229(16.9)$ & $1576(16 \cdot 7)$ & $271(19 \cdot 2)$ & $75(16.8)$ & $42(17 \cdot 1)$ \\
\hline Heart failure & $10(9.9)$ & $29(11.5)$ & $141(10.4)$ & $903(9.5)$ & $145(10 \cdot 3)$ & $53(11.9)$ & $26(10.6)$ \\
\hline Cirrhosis & $9(8.9)^{*}$ & $18(7 \cdot 1)^{*}$ & $49(3.6)$ & 289 (3) & $56(4)$ & $26(5 \cdot 8)^{*}$ & $2(0.8)$ \\
\hline $\begin{array}{l}\text { Chronic renal } \\
\text { failure }\end{array}$ & $8(7.9)$ & $29(11.5)$ & $128(9 \cdot 4)$ & $858(9 \cdot 1)$ & $134(9.5)$ & $44(9.9)$ & $22(9)$ \\
\hline IDDM & $13(12 \cdot 1)$ & $39(15.4)^{*}$ & $136(10)$ & $858(9.1)$ & $188(13.3)^{*}$ & $36(8.1)$ & $30(12 \cdot 2)$ \\
\hline $\begin{array}{l}\text { Solid organ } \\
\text { cancer }\end{array}$ & $27(26 \cdot 7)$ & $41(20 \cdot 1)$ & $274(20 \cdot 1)$ & $1765(17 \cdot 4)$ & $234(16 \cdot 5)$ & $90(20 \cdot 1)$ & $46(21.8)$ \\
\hline $\begin{array}{l}\text { Haematological } \\
\text { cancer }\end{array}$ & $1(1)$ & $4(1.6)$ & $30(2 \cdot 2)$ & $200(2 \cdot 1)$ & $24(1.7)$ & $15(3.4)$ & $5(2)$ \\
\hline HIV & $1(1)$ & $4(1.6)$ & $15(1 \cdot 1)$ & $55(0.6)$ & $8(0.6)$ & $5(1 \cdot 1)$ & $3(1.2)$ \\
\hline Infection & $58(57 \cdot 4)$ & $155(61 \cdot 3)^{*}$ & $788(58)^{*}$ & $4515(47 \cdot 7)$ & $914(64 \cdot 8)^{*}$ & $310(69 \cdot 5)^{*}$ & $174(71)^{*}$ \\
\hline \multicolumn{8}{|l|}{ ICU interventions } \\
\hline $\begin{array}{l}\text { Mechanical } \\
\text { ventilation }\end{array}$ & $44(44)$ & $126(50)$ & $681(50 \cdot 1)$ & $5037(53.3)$ & $1054(74 \cdot 8)^{*}$ & $351(78.9)^{*}$ & $203(82.9)^{*}$ \\
\hline $\begin{array}{l}\text { Haemodialysis/ } \\
\text { filtration }\end{array}$ & $10(10 \cdot 1)$ & $30(11.9)$ & $187(13.8)^{*}$ & $879(9.3)$ & $98(7)^{*}$ & $23(5 \cdot 2)^{*}$ & $14(5.7)$ \\
\hline \multicolumn{8}{|l|}{ Type of admission } \\
\hline Elective surgery & $6(5.9)^{*}$ & $42(16 \cdot 7)^{*}$ & $251(18.5)^{*}$ & $2436(25.8)$ & $263(18.7)^{*}$ & $63(14.8)^{*}$ & $33(13.5)^{*}$ \\
\hline
\end{tabular}


Table 1 Continued

\begin{tabular}{|c|c|c|c|c|c|c|c|}
\hline & $\begin{array}{l}\mathrm{Na}<125 \\
\mathrm{mM} / \mathrm{L} \\
n=101\end{array}$ & $\begin{array}{l}125<\mathrm{Na} \leq 129 \\
\mathrm{mM} / \mathrm{L} \\
n=253\end{array}$ & $\begin{array}{l}130<\mathrm{Na} \leq 134 \\
\mathrm{mM} / \mathrm{L} \\
n=1359\end{array}$ & $\begin{array}{l}\text { Na normal } \\
(135-145 \mathrm{mM} / \mathrm{L}) \\
n=9461\end{array}$ & $\begin{array}{l}146<\mathrm{Na} \leq 150 \\
\mathrm{mM} / \mathrm{L} \\
n=1411\end{array}$ & $\begin{array}{l}151<\mathrm{Na} \\
\leq 155 \mathrm{mM} / \mathrm{L} \\
n=446\end{array}$ & $\begin{array}{l}\mathrm{Na}>155 \\
\mathrm{mM} / \mathrm{L} \\
n=245\end{array}$ \\
\hline Medical & $56(55.4)^{*}$ & $74(29.5)$ & $395(29 \cdot 2)$ & $2567(27 \cdot 1)$ & $403(28.6)$ & $145(32.5)$ & $71(29 \cdot 1)$ \\
\hline $\begin{array}{l}\text { Emergency } \\
\text { surgery }\end{array}$ & $32(31.7)$ & $114(45 \cdot 9)$ & $560(41.3)^{*}$ & $3535(37.4)$ & $602(42 \cdot 7)^{*}$ & $183(41)$ & $104(42 \cdot 6)$ \\
\hline Trauma & $7(6.9)$ & $21(8.4)$ & $149(11)$ & $911(9.6)$ & $142(10 \cdot 1)$ & $52(11.7)$ & $36(14.8)$ \\
\hline
\end{tabular}

COPD, chronic obstructive pulmonary disease; HIV, human immunodeficiency virus; IDDM, insulin-dependent diabetes mellitus; SAPS, Simplified Acute Physiology Score.

*Statistical significance at $5 \%$ level vs. normal group.

normal range; 1713 patients $(12.9 \%)$ had hyponatraemia [1359 (79.3\%) mild, 253 (14.8\%) moderate and 101 (5.9\%) severe]; and $2102(15.8 \%)$ patients had hypernatraemia [1411 (67.1\%) mild, $446(21.2 \%)$ moderate and $245(11.7 \%)$ severe]. Patient characteristics according to the different serum sodium groups are shown in Table 1. SAPS II and SOFA scores were significantly higher in patients with all degrees of dysnatraemia than in those with normal sodium levels. Hypernatraemia was more common than normonatraemia in mechanically ventilated patients. Patients with hypernatraemia and mild hyponatraemia had longer lengths of ICU stay prior to the study day than those with normonatraemia.

Of the 13276 measurements, 3425 (25.8\%) were made in patients who were admitted on the study day and 9851 (74.2\%) in patients who were already present in the ICU. In patients admitted on the study day, the prevalence of hyponatraemia $(12.3 \%)$ and hypernatraemia $(12.1 \%)$ was similar $(P=0.81)$, whereas hypernatraemia was more frequent than hyponatraemia in patients already in the ICU (17.1\% vs. $13 \cdot 1 \%$, $P<0.001)$.

\section{Relation with mortality and length of stay}

There were significant differences in ICU and hospital lengths of stay among the groups of patients with dysnatraemia $(P<0.001)$ (Table 2). Hospital mortality rates for the different groups also differed (Table 2), following a U-shaped pattern (Fig. 1) with higher rates for severe dysnatraemia; hospital mortality reached more than $50 \%$ for patients with severe hypernatraemia. Hospital mortality rates were similar in patients with dysnatraemia already present in the ICU compared with those admitted on the study day both for hyponatraemia (28.8\% vs. $29.3 \%$ ) and hypernatraemia $(39.2 \%$ vs. $35 \cdot 3 \%$ ). Adjusted ORs for hospital mortality also had a U shape with higher values at the extreme sodium values (Fig. 2). The association between dysnatraemia and hospital mortality was observed in infected as well as in noninfected patients and was not statistically different between the two groups of patients $(P=0.061)$ (Fig. 3$)$.

\section{Discussion}

In this study, we investigated the frequency of dysnatraemia and its effect on mortality in a large, mixed population of medical and surgical patients in 1265 ICUs across 76 countries. Dysnatraemia was common, affecting $29 \%$ of ICU patients, and was independently associated with increased hospital mortality.

The higher incidence of hypernatraemia in patients already being treated in the ICU (17.1\%) compared with newly admitted patients $(12.1 \%)$ is in accordance with the results of other series [13-15]. In a retrospective monocentre study, Lindner et al. [13] reported that the majority of cases of hypernatraemia (defined as a serum sodium $>149 \mathrm{mM} / \mathrm{L}$ ) in the ICU developed during the ICU stay (2\% hypernatraemia on admission vs. $7 \%$ during the ICU stay). These authors did not find a difference in mortality (39\% vs. 43\%) between the two subgroups. Using a similar cut-off of serum sodium (> $150 \mathrm{mM} / \mathrm{L}$ ), the incidence of hypernatraemia in our database - defined as moderate to severe hypernatraemia according to our criteria - was $3.6 \%$ at admission and $5.7 \%$ during the ICU stay, and we also found no significant difference in mortality rates between these groups of patients (40.0\% vs. $49.5 \%$, $P=0.27)$. In a French multicentre cohort, using the same cutoff value of $150 \mathrm{mM} / \mathrm{L}$, hypernatraemia was observed in $3.6 \%$ of patients at ICU admission and in $14.7 \%$ of patients already treated in the ICU [14]. In a recent large cohort of ICU patients, Waite et al. [16] reported that hypernatraemia (defined as serum $\mathrm{Na}>149 \mathrm{mM} / \mathrm{L}$ ) developed after admission in $4.3 \%$ of patients and was independently associated with an increased risk of hospital mortality [relative risk (RR) 1.40 (95\% confidence interval, 1.34-1.45)] and ICU length of stay. All these results suggest an iatrogenic component for the hypernatraemia occurring during the ICU stay. Some authors have suggested that the incidence of hypernatraemia in the ICU is an indicator of the quality of care [17].

The mechanisms involved in the development of hypernatraemia during the ICU stay include sodium gain and/or loss 


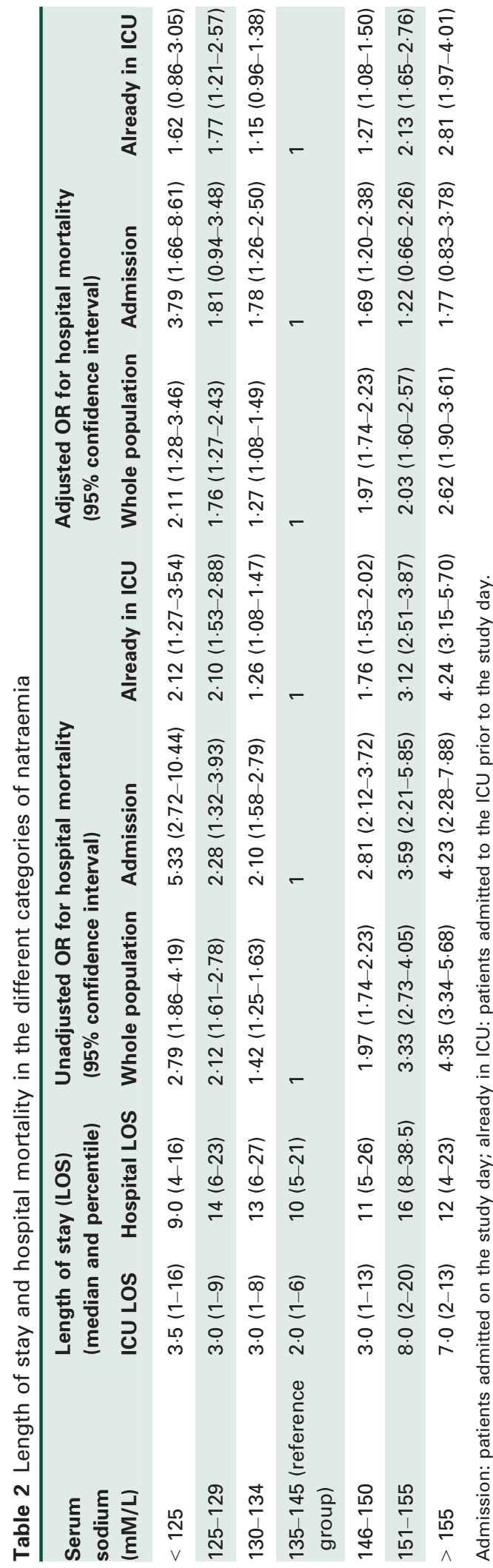

of free water and can be discriminated by clinical assessment and urine electrolyte analysis [18]. Because many critically ill patients have impaired levels of consciousness, their water balance can no longer be regulated by thirst. This applies particularly to patients receiving mechanical ventilation, which was associated with more frequent development of hypernatraemia in our cohort. In a monocentre case-control study including 130 cases of hypernatraemia, Hoorn et al. [19] showed that hypernatraemia was more commonly associated with sepsis, hypokalaemia, renal dysfunction, hypoalbuminaemia and the use of mannitol and sodium bicarbonate (17). Natraemia $>150 \mathrm{mM} / \mathrm{L}$ was associated with an almost fivefold increase in mortality rate ( $48 \%$ vs. $10 \%$ ). Interestingly, fluid balance was positive in $38.4 \%$ of patients. We were unable to estimate fluid balance in our database because, although 24-h urine output was collected on the study day, fluid intake was not collected.

Data regarding the incidence and the prognostic value of hyponatraemia on admission compared with during the ICU stay are scarcer. In our series, the crude hospital mortality of patients with hyponatraemia was similar in the two groups. The difference in the incidence of hyponatraemia between newly admitted patients and patients already on the ICU (12.3\% vs $13.1 \%$ respectively) was lower than for hypernatraemia (13.1\% vs. $17 \cdot 1 \%$, respectively). In their study on the epidemiology of ICU-acquired dysnatraemia, Stelfox et al. [8] reported a higher incidence of ICU-acquired hypernatraemia (26\%) than of ICU-acquired hyponatraemia (11\%), but these authors included serum sodium values of 133 and $134 \mathrm{mM} / \mathrm{L}$ in their normal range. In contrast, using a threshold of $135 \mathrm{mM} / \mathrm{L}$ to define hyponatraemia, Sakr et al. [15] found a higher incidence of ICU-acquired hyponatraemia (13.6\%) than ICU-acquired hypernatraemia $(9.1 \%)$ in a series of about 11000 surgical ICU patients. In our series, dysnatraemia observed in patients already in the ICU on the study day cannot be strictly considered as ICU-acquired dysnatraemia as the condition may has already been present prior to ICU admission. This represents a limitation to the comparison with other series and in particular that of Sakr et al. [15], in which dysnatraemia at ICU admission was associated with a higher risk of in-hospital death, compared with ICU-acquired dysnatraemia. In our study, hospital mortality was not statistically different in patients with dysnatraemia admitted in the ICU on the study day than in those already present in the ICU on the study day, although there a was a tendency towards a lower mortality in this latter group.

Our study documented the U-shaped pattern of mortality described in earlier studies of ICU and non-ICU populations [4-7], with greater mortality rates at the extreme values of both hypo- and hypernatraemia. Interestingly, the only adjusted OR for hospital mortality that did not follow the U-shaped pattern 


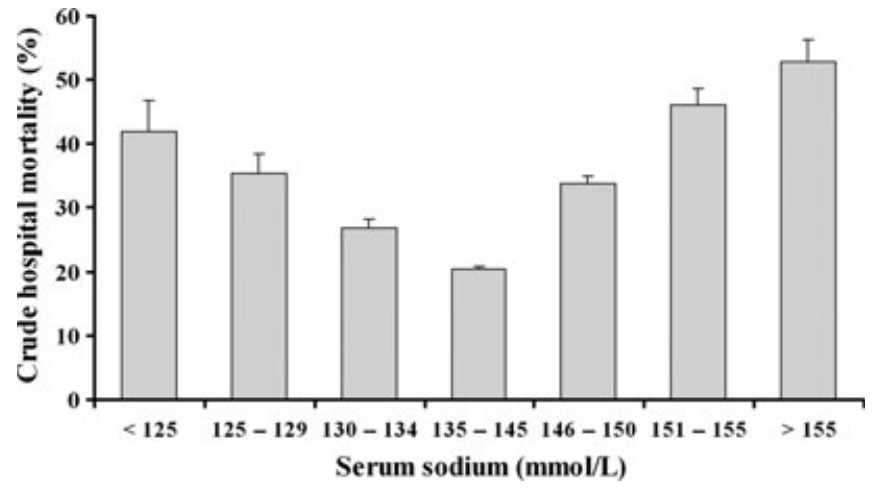

Figure 1 Crude hospital mortality in the different categories of natraemia.

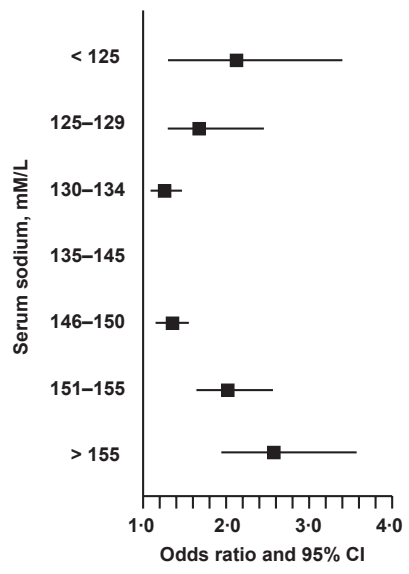

Figure 2 Adjusted odds ratios for hospital mortality among the different categories of natraemia.

was that of patients already in the ICU who had severe hyponatraemia, an observation also made in the series by Funk et al. [4]. The association between dysnatraemia and mortality was present in infected and noninfected patients, but was not different between these groups. Waikar et al. [6] studied the influence of hyponatraemia on in-hospital, 1-year and 5-years mortality rates in a large population of more than 98000 unselected adult patients. Although these authors observed a close relationship between hyponatraemia - even when mild and hospital mortality, mortality was not increased in patients with septic hyponatraemia, for any degree of hyponatraemia. However, their population was not an ICU cohort, which suggests a difference in the degree of severity of sepsis and organ dysfunctions.

This study has several strengths and limitations. The EPIC II study was a multicentre worldwide cohort. The strength of a point prevalence study is to eliminate any variability in treat-

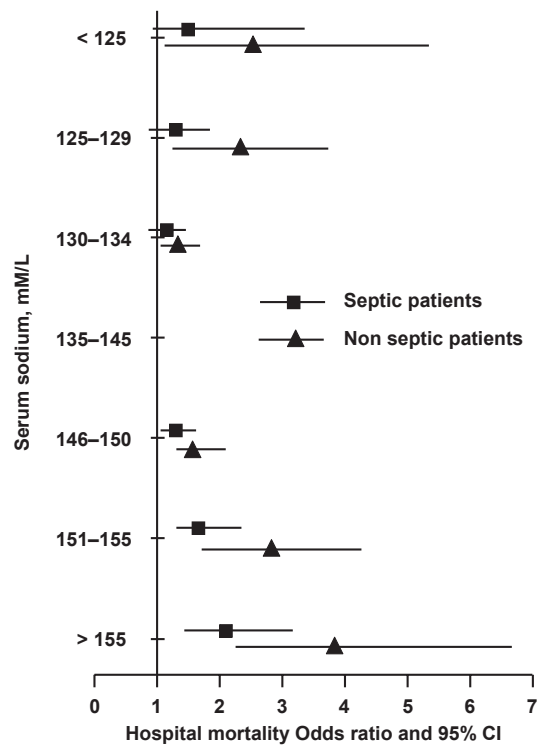

Figure 3 Adjusted odds ratios for hospital mortality in patients with or without infection in the different categories of natraemia.

ments that may occur over the years, as has been the case in some other studies [4,7]. In particular, intravenous fluid dose and composition have changed over the years as individualized goal-directed fluid therapy has become more common [20]. The limitation of a point prevalence study is the lack of information about the time course of these abnormalities and factors that may have contributed to the development of dysnatraemia during the ICU stay. In addition, we did not collect data on therapeutic decisions likely to influence natraemia, such as the nature and amount of fluid administered or other forms of treatment, including diuretics or vasopressin derivatives. Another potential limitation is that the data were obtained several years ago; nevertheless, although there have been some changes in the overall management of critically ill patients during that time, the treatment of dysnatraemia has not changed much. Finally, the prognostic value of dysnatraemia in ICU patients does not necessarily imply a cause-and-effect relationship; rather dysnatraemia may be a surrogate marker for severity of underlying disease. Nevertheless, dysnatraemia and associated conditions probably act as additive mechanisms leading to death. This possible mechanism has also been suggested by Hoorn et al. [21] in a recent review on hyponatraemia and mortality: the underlying disease causes hyponatraemia and contributes to mortality, but hyponatraemia further increases this mortality risk.

In conclusion, we have shown that dysnatraemia in the ICU is an independent predictor of increased hospital mortality, whatever the degree of hypo- or hypernatraemia and whenever 
the dysnatraemia is recorded (at admission or during the ICU stay). There is a clear U-shaped relationship between the severity of the hypo- and hypernatraemia and mortality (in other words a 'dose-response effect'). This link between dysnatraemia and mortality supports the need for a prospective, controlled trial to investigate the impact of tight natraemic control on outcome. A challenge for such a trial would be to elaborate a therapeutic algorithm for the correction of dysnatraemia.

\section{Acknowledgements}

We thank Hassane Njimi, MSc, PhD, Department of Intensive Care, Erasme University Hospital, Brussels, Belgium, for his help with the data management and statistical analyses.

\section{Conflict of interests}

The authors declare they have no conflict of interests related to this article.

\section{Address}

Department of General Internal Medicine, Erasme Hospital, Université libre de Bruxelles, Route de Lennik 808, B-1070 Brussels, Belgium (F. Vandergheynst); Department of Anesthesiology and Intensive Care, Friedrich-Schiller University, Uniklinikum Jena, Erlanger Allee 101, 07743 Jena, Germany (Y. Sakr); Department of Intensive Care, Swiss Paraplegic Centre, Guido A. Zächstrasse 1, CH- 6207 Nottwil, Switzerland (P. Felleiter); Department of Anesthesiology and Intensive Care Medicine, Kreiskrankenhaus Mechernich and University of Bonn, St.Elisabeth-Strasse 2-6, 53894 Mechernich, Germany (R. Hering); Department of Intensive Care, Erasmus Medical Center's, Gravendijkwal 230, 3015 Rotterdam, The Netherlands (J. Groeneveld); Service d'Hygiène, Epidémiologie et Prévention, Hospices Civils de Lyon, Hôpital Edouard Herriot, Université de Lyon 1, 5, place d'Arsonval, 69437 Lyon, Cedex 03, France (P. Vanhems); Laboratoire de Biométrie et de Biologie Evolutive, Equipe Epidémiologie et Santé Publique, CNRS UMR 5558, Lyon, France (P. Vanhems); Department of Intensive Care, Erasme Hospital, Université Libre de Bruxelles, Brussels, Belgium (F. S. Taccone, J.-L. Vincent).

Correspondence to: Frédéric Vandergheynst, Department of General Internal Medicine, Erasme Hospital, Université libre de Bruxelles, Route de Lennik 808, B-1070 Brussels, Belgium. Tel.: 02555 3806; fax: 02555 3211; e-mail: fvdgheyn@ulb.ac.be

Received 10 May 2013; accepted 5 June 2013

\section{References}

1 Le Gall JR, Lemeshow S, Saulnier F. A new Simplified Acute Physiology Score (SAPS II) based on a European/North American multicenter study. JAMA 1993;270:2957-63.
2 Milo-Cotter O, Cotter G, Weatherley BD, Adams KF, Kaluski E, Uriel $\mathrm{N}$ et al. Hyponatraemia in acute heart failure is a marker of increased mortality but not when associated with hyperglycaemia. Eur J Heart Fail 2008;10:196-200.

3 Serste T, Gustot T, Rautou PE, Francoz C, Njimi H, Durand F et al. Severe hyponatremia is a better predictor of mortality than MELDNa in patients with cirrhosis and refractory ascites. J Hepatol 2012;57:274-80.

4 Funk GC, Lindner G, Druml W, Metnitz B, Schwarz C, Bauer P et al. Incidence and prognosis of dysnatremias present on ICU admission. Intensive Care Med 2010;36:304-11.

5 Whelan B, Bennett K, O'Riordan D, Silke B. Serum sodium as a risk factor for in-hospital mortality in acute unselected general medical patients. QJM 2009;102:175-82.

6 Waikar SS, Mount DB, Curhan GC. Mortality after hospitalization with mild, moderate, and severe hyponatremia. Am J Med 2009;122:857-65.

7 Darmon M, Diconne E, Souweine B, Ruckly S, Adrie C, Azoulay E et al. Prognostic consequences of borderline dysnatremia: pay attention to minimal serum sodium change. Crit Care 2013;17:R12.

8 Stelfox HT, Ahmed SB, Khandwala F, Zygun D, Shahpori R, Laupland $\mathrm{K}$. The epidemiology of intensive care unit-acquired hyponatraemia and hypernatraemia in medical-surgical intensive care units. Crit Care 2008:12:R162.

9 Vincent JL, Rello J, Marshall J, Silva E, Anzueto A, Martin CD et al. International study of the prevalence and outcomes of infection in intensive care units. JAMA 2009;302:2323-9.

10 Calandra T, Cohen J. The international sepsis forum consensus conference on definitions of infection in the intensive care unit. Crit Care Med 2005;33:1538-48.

11 Rubin DB. Estimating causal effects from large data sets using propensity scores. Ann Intern Med 1997;127:757-63.

12 Rubin DB. For objective causal inference, design trumps analysis Ann Appl Stat 2008;2:808-40.

13 Lindner G, Funk GC, Schwarz C, Kneidinger N, Kaider A, Schneeweiss B et al. Hypernatremia in the critically ill is an independent risk factor for mortality. Am J Kidney Dis 2007;50:952-7.

14 Darmon M, Timsit JF, Francais A, Nguile-Makao M, Adrie C, Cohen $\mathrm{Y}$ et al. Association between hypernatraemia acquired in the ICU and mortality: a cohort study. Nephrol Dial Transplant 2010;25:2510-5.

15 Sakr Y, Rother S, Ferreira AM, Ewald C, Dunisch P, Riedemmann N et al. Fluctuations in serum sodium level are associated with an increased risk of death in surgical ICU patients. Crit Care Med 2013;41:133-42.

16 Waite MD, Fuhrman SA, Badawi O, Zuckerman IH, Franey CS Intensive care unit-acquired hypernatremia is an independent predictor of increased mortality and length of stay. J Crit Care 2013. doi: 10.1016/j.jcrc.2012.11.013. [Epub ahead of print])

17 Polderman KH, Schreuder WO, Strack van Schijndel RJ, Thijs LG. Hypernatremia in the intensive care unit: an indicator of quality of care? Crit Care Med 1999;27:1105-8.

18 Lindner G, Funk GC. Hypernatremia in critically ill patients. J Crit Care 2012;28:216.e11-20.

19 Hoorn EJ, Betjes MG, Weigel J, Zietse R. Hypernatraemia in critically ill patients: too little water and too much salt. Nephrol Dial Transplant 2008;23:1562-8.

20 Raghunathan K, McGee WT, Higgins T. Importance of intravenous fluid dose and composition in surgical ICU patients. Curr Opin Crit Care 2012;18:350-7.

21 Hoorn EJ, Zietse R. Hyponatremia and mortality : moving beyond associations. Am J Kidney Dis 2013;62:139-49. 


\section{Appendix}

\section{List of participating centres by country, alphabetically}

Andorra: Hospital Nostra Senyora de Meritxell (A. Margarit); Argentina: Centro de Educación Médica E Investigaciones Clínicas (R. Valentini); Clinica de Especialidades Villa Maria (A. J. Zazu); Clínica Modelo de Morón (C. Bevilacqua); Clinica Y Maternidad Suizo (M. Curone); CMIC (R. Rabuffetti); Hospital Aleman (P. Comignani); Hospital Argerich (M. Torres Boden); Hospital Britanico (F. Chertcoff); Hospital Central de San Isidro (G. Cardonatti); Hospital de Niños Dr. Héctor Quintana (F. Adén); Hospital del Niño Jesús (L. Marcos); Hospital Dr Pedro Ecay (M. Dónofrio); Hospital Español de Mendoza (R. Fernández); Hospital Español Medical Plaza (R. Lamberghini); Hospital Internacional General de Agudos 'José de San Matín' (S. Balasini); Hospital Interzonal Dr. O.Alende (J. Teves); Hospital Italiano de Buenos Aires (M. Las Heras, J Sinner); Hospital Juan A. Fernández (D. Ceraso); Hospital Municipal de Chivilcoy (D. Curcio); Hospital Profesor Alejandro Posadas (L. Aguilar); Hospital Provincial de Rosario (C. Weller); Hospital Provincial del Centenario (L. Cardonnet); Hospital Regional Rio Gallegos (R. Santa Cruz); Hospital Regional Ushuaia (E. Manrique); Hospital Universitario Austral (D. Bernardez, T. Iolster); Hospital Universitario Universidad Abierta Interamericana (G. Chiappero); Instituto Privado del Quemado Med-Inter (D. Curcio); Nuevo Hospital El Milagro (P. Ramos); Ramos Mejia Hospital (J. Vergara); Sanatorio Agote (I. Moine); Sanatorio de la Trinidad Mitre (S. Ilutovich); Sanatorio de Los Arcos (G. Jannello); Sanatorio Dupuytren (M. Waschbusch); Sanatorio Frangioli de Salud 2000 Srl (G. Rios Picaza); Sanatorio Mater Dei (A. Raimondi); Sanatorio Otamendi Y Miroli (M. Miriam); Sanatorio Parque (L. Carlos); Sanatorio San José (D. Curcio); Armenia: Centro Gallego de Buenos Aires (M. Caridi); Australia: Alfred Hospital (T. Leong); Barwon Health (N. Orford); Blacktown Hospital (G. Reece); Box Hill Hospital (D. Ernest); Cabrini Hospital (F. Hawker); Concord Repatriation General Hospital (J. Tan); Epworth Eastern Private Hospital (C. Giannellis); Epworth Hospital Richmond (B. Ihle); Flinders Medical Centre (A. Bersten); Frankston Hospital (J. McInnes); Gold Coast Hospital (M. Tallott); John Hunter Hospital (B. Mcfadyen); Joondalup Health Campus (J. Vibert); Liverpool Hospital, Sydney South West Area Health Service (M. Parr); Logan Hospital (K. Tran); Mater Health Services (J. Sutton); Mount Hospital (S. Webb); Nambour General Hospital (N. Groves); Nepean Hospital, NSW (L. Cole); Prince Charles Hospital (D. Long); Prince of Wales Hospital (F. Bass); Princess Margaret Hospital For Children (S. Erickson); Royal Brisbane and Womens' Hospital (J. Lipman); Royal Children's Hospital, Brisbane (D. Long); Royal Children's Hospital,
Melbourne (C. Delzoppo); Royal Darwin Hospital (J. Thomas); Royal Perth Hospital (G. Dobb); Royal Prince Alfred Hospital (M. Daley); Sir Charles Gairdner Hospital (B. Roberts); St John of God Hospital, Subiaco (S. Webb); St Vincent's Hospital, Melbourne (J. Santamaria); Sydney Children's Hospital (J. Young); The Children's Hospital at Westmead, Sydney (M. Festa); The John Flynn Private Hospital (R. Holland); The Prince Charles Hospital (D. Mullany); The Queen Elizabeth Hospital (P. Williams); The Townsville Hospital (M. Corkeron); The Wollongong Hospital (M. Gales); Westmead Hospital (A. Banerjee); Women's and Children's Hospital, Adelaide (M. Yung); Austria: University Hospital Innsbruck (N. Mutz, M. Hiesmayr); General Hospital (P. Faybik); Hospital Hietzing (R. Fitzgerald); Krankenhaus Barmherzige Brüder Linz (F. Firlinger); Krankenhaus Der Barmherigen Brueder Wien (G. Zasmeta); Krankenhaus Der Barmherzigen Brüder St. Veit (M. Zink); Krankenhaus Der Barmherzigen Schwestern Linz (W. Sieber); Krankenhaus Steyr (J. Hildegard); Landeskrankenhaus Klagenfurt (R. Bakondy); Landeskrankenhaus Stolzalpe (J. Schlieber); Landeskrankenhaus Deutschlandsberg (G. Filzwieser); Medical University Innsbruck (R. Beer, M. Joannidis); Medical University of Vienna (T. Staudinger); Otto-Wagner Hospital (R. Schuster); Unfallkrankenhaus Meidling Der Auva (W. Scherzer); University Hospital (K. Smolle); Wilhelminenspital (S. Fitzal); Bangladesh: Central Hospital Limited (R. Manzoor); Belgium: A.I.T. (J. Brunain); Ambroise Paré (A. Dive); Asz-Aalst (G. Huylenbroeck); Az Groeninge Kortrijk (M. Van der Schueren); Az Maria Middelares (H 't kindt); Az Sint Jozef Malle (E. Slock); Az Sint Lucas (D. Rijckaert); Az St Augustinus (J. Raemaekers); Az St Jan Av (M. Bourgeois); Az Vesalius (I. Van Cotthem); Az Damiaan Oostende (G. Nackaerts); C.H.N.D.R.F. (D. Gusu); Centre Hospitalier de Mouscron (P. Gadisseaux); $\mathrm{CH}$ Libramont (V. Olivier); Chirec - Braine-L'Alleud (H. Lignian); CHPLT Verviers (P. Michel); CHR Citadelle (V. Fraipont); CHR Haute Senne Soignies (M. Vander Stappen); CHR St Joseph Mons-Warquignies (F. Forêt); CHU Brugmann (D. De Bels, J. Devriendt, J. Massaut); CHU Charleroi (P. Biston); CHU Saint-Pierre (A. Roman); CHU Sart Tilman, Liège (B. Lambermont); Clinique Sainte Elisabeth (A. De Meulder); Clinique Notre Dame (V. Frederic); Clinique Notre-Dame de Grâce (T. Sottiaux); Clinique Saint Luc, Bouge (P. Ruyffelaere); Cliniques de L'Europe, St-Michel (V. Collin); Cliniques de L'Europe, Ste Elisabeth (S. Anane); Hôpital Francais (P. Kleiren); Hôpital Saint-Joseph (M. Simon); Hornu (S. Machayekhi); Imeldaziekenhuis (E. Frans); Institut Jules Bordet (G. Leroy, T. Berghmans); Jan Yperman Hospital (R. Joseph); Olv Ter Linden Ziekenhuis, Knokke (J. Eerens); Saint Luc University Hospital (P. F. Laterre); Sint Augustinus, Veurne (B. Lagrou); St Vincent (R. Rutsaert); St-Jozefkliniek BornemWillebroek (W. Pisarek); UCL Mont-Godinne (A. Dive); 
Universitair Ziekenhuis Gent (J. De Waele); University Hospital Brussels (H. Spapen); University Hospital of Liege (P. Damas); Erasme University Hospital (J. L. Vincent); ZNA Stuivenberg (M. Malbrain); Belize: Universal Health Services, Medical Center (J. Hidalgo); Brazil: Bandeirantes Hospital (M. Baptista); Barra Dor Hospital (D. Salgado); Biocor Instituto (M. Braga); Casa de Saude Sao Jose Caxias (C. Avila); Centro Hospitalar Unimed (G. Westphal); Centro Integrado de Atençaõ À Saúde -Unimed Vitória (E. Caser); Clínica São Vicente da Gávea (A. Alves); Complexo Hospitalar Santa Casa de Porto Alegre (G. Friedman); Erasto Gaertner Hospital (M. Luz); Federal University of Sao Paulo (M. Assuncao); Fundacao Hospital de Clinicas Gaspar Vianna (H. Reis); Fundação Hospitalar Do Estado de Minas Gerais - Fhemig (A. Gomes); Fundação Pio Xii (U. Silva); UNIFESP (W. Nogueira Fh); Hopital das Clínicas FMUSP (S. El-Dash); Hospital Padre Albino-Faculdade de Medicina de Catanduva (J. Valiatti); Hospital Alberto Cavalcanti (A. Barbosa); Hospital Badim (C. Coelho); Hospital Cardiotrauma Ipanema (M. Knibel); Hospital Carlos Fernando Malzoni (C. Minelli); Hospital Da Cidade de Passo Fundo (J. Caovilla); Hospital das Clínicas da Faculdade de Medicina de Ribeirão Preto da Universidade de São Paulo (G. Teixeira); Hospital das Clínicas, Universisty of São Paulo (A. Hovnanian); Hospital das Nacoes (A. Rea-Neto); Hospital de Base-Famerp (S. L. Lobo); Hospital de Clínicas Mario Lioni (M. Lugarinho); Hospital de Clínicas Niterói (P. Souza); Hospital de Doenças Tropicais de Goiânia (D. Ferreira); Hospital do Cancer/ Uopeccan (P. Duarte); Hospital do Trabalhador (M. Oliveira); Hospital dos Servidores do Estado Rio de Janeiro (J. Marques); Hospital E Maternidade São José (R. Machado); Hospital Estadual Diadema (P. Rehder); Hospital Estadual do Grajau-Unisa (S. Mataloun); Hospital Evangelico (M. Grilo); Hospital Evangelico do Rio de Janeiro (P. Quesado); Hospital Geral de Pedreira (M. Moock); Hospital Geral de São Mateus

(F. Ferreira); Hospital Geral Roberto Santos (J. Teles); Hospital Israelita Albert Einstein (E. Silva); Hospital Israelita Albert Sabin (C. Coelho); Hospital Júlia Kubitschek (A. Morais); Hospital Mater Dei (F. Carvalho); Hospital Memorial Arthur Ramos (M. Wanderley); Hospital Meridional (M. Velasco); Hospital Moinhos de Vento (N. Brandão da Silva); Hospital Municipal São José (J. Feijó); Hospital Nossa Senhora Da Salete (P. Duarte); Hospital Pasteur (V. Souza Dantas); Hospital Português (J. Teles); Hospital Pró-Cardíaco (R. Costa Filho); Hospital Quinta D'Or (A. Japiassu); Hospital Regional Antônio Dias (D. Villela); Hospital Regional de Barbacena (C. Santos); Hospital Salvador (R. Passos); Hospital Samaritano (R. AlheiraRocha); Hospital Santa Izabel (R. Silva); Hospital Santa Paula (J. Houly); Hospital Sao Cristovao (J. Aldrighi); Hospital São Lucas (R. Hatum); Hospital São Lucas da PUCRS (F. Suparregui Dias); Hospital São Luiz - Unidade Itaim (L. Ferreira); Hospital São Rafael (L. Ferro); Hospital São Vicente de Paulo (J. Gomez);
Hospital Universitário Clementindo Fraga Filho - Ufrj (R. Fleury); Hospital Universitario da Universidade Federal do Rio de Janeiro (C. David); Hospital Universitário de Santa Maria (T. Resener); Hospital Universitário do Oeste do Paraná (P. Duarte); Hospital Universitário Lauro Wanderley - UTI Adulto (C. Mendes); Hospital Universitario Regional de Maringa (A. Germano); Hospital Vita Curitiba (M. Oliveira); Hospital Vivalle (F. De marco); Instituto de Espquisa Clinica Evandro Chagas (A. Japiassu); Instituto Do Coração - HCFMUSP (S. Lage); Instituto Nacional de Cancer (J. Salluh); Irmandade Santa Casa de Misericordia de Porto Alegre (A. Torelly); Luxemburgo Hospital (R. Sad); Mternidade Odete Valadares (A. Barbosa); Prontocor Lagoa (G. Oliveira); Samaritano Hospital (R. Lima); Santa Casa Da Misericórdia de São João del Rei (J. Paranhos); Santa Casa de Misericordia de Passos (M. Oliveira); Santa Casa de Porto Alegre (M. Rocha); São Sebastião Hospital (W. Bitencourt); Universidade Federal Do Parana (A. Rea-Neto); University of Londrina (C. Grion); University of Sao Paulo (D. Forte); Uti Da Disciplina de Clínica Médica-Unifesp (H. Guimarães); Vitória Apart Hospital (C. Piras); Bulgaria: Mbal Ruse (L. Stephanova); Multiprofile Hospital of Active Treatment, Ruse (L. Lyubenov); Uh St. Ekaterina (G. Tsarianski); Univerisity Hospital (G. Dimov); Canada: Capital Health-Queen Elizabeth II Health Sciences Centre (R. Green); Centre Hospitalier Régional de Lanaudière (J. Levasseur); Children's Hospital of Eastern Ontario (R. Ward); CHU Sherbrooke (O. Lesur); Hôpital Charles Lemoyne (G. Poirier); Mount Sinai Hospital (R. Wax); Royal Jubilee Hospital (G. Wood); St. Joseph's Healthcare (D. Cook); St. Michael's Hospital (J. Marshall); Toronto General Hospital (M. Herridge); Toronto Western Hospital (N. Ferguson); Victoria General Hospital (G. Wood); Chile: Clinica Alemana de Santiago (M. Espinoza); Clinica las Condes (S. Valdés jimenez); Hospital Clínico de la Pontificia Universidad Católica de Chile (A. Bruhn); Hospital del Trabajador (J. Micolich); Hospital Dr G. Fricke (S. Galvez); Hospital El Pino (I. Escamilla Leon); China: Beijing Chaoyang Hospital (Q. Zhan); Beijing Tongren Hospital (Y. Xu); Chinense Pla General Hospital (Y. Zhao); Fuxing Hospital, Capital Medical University (L. Zhang); Guangdong Provincial People's Hospital (T. Qin); Peking Union Medical College Hospital (B. Du); Peking University People's Hospital (M. Li); Ren Ji Hospital,Shanghai Jiao Tong University (X. Wang); The Affiliated Hospital of Ningxia Medical College of China (Y. Jing); The First Affiliate Hospital of China Medical University (Z. Zhang); The First Affiliated Hospital of Dalian Medical University (W. Xianyao); The First People's Hospital of Nantong, Jiangsu (F. Li); Zhong-Da Hospital and School of Clinical Medicine, Southeast University (Y. Congshan); Colombia: Clinica General del Norte (C. Rebolledo); Clinica Central del Quindio (D. Diaz); Clinica Medellin (R. Murillo Arboleda); Clinica Saludcoop (C. Rebolledo); Clinica 
Santa Isabel de Valledupar. (A. Arias Antun); Fundación Hospital San Carlos (G. Montenegro); Fundacion Valle del Lili (M. Granados); Hospital Bocagrande de Cartagena (C. Duenas); Hospital Departamental de Villavicencio (N. Perez); Hospital El Tunal (G. Libreros Duque); Hospital San Jose de Bogota (M. Coral); Hospital Santa Clara (G. Ortiz); Costa Rica: Hospital Calderón Guardia CCSS (D. Rodriguez); Croatia: Hospital for Infectious Diseases (B. Barsic); Sveti Duh General Hospital, School of Medicine, Zagreb (M. Cubrilo-Turek); University Hospital Centre (I. Gornik); University Hospital Zagreb (M. Grljusic); Cuba: Hospital Universitario Arnaldo Milian Castro (A. Caballero lopez); Hospital Universitario Dr. Gustavo Aldereguía Lima (M. Iraola ferrer); Czech Republic: Centre of Cardivascular and Transplant Surgery (P. Pavlik); Charles University Teaching Hospital, Hradec Kralove (J. Manak); Charles University Medical School and Teaching Hospital (J. Radej); Faculty General Hospital, Charles University Prague (J. Belohlavek); Faculty Hospital Brno (P. Sevcik); Faculty Hospital Olomouc (L. Blahut); General Teaching Hospital of 1St Faculty and Charles University (D. Tyl); Horovice Hospital (J. Steinbach); Klaudians Hospital (I. Herold); Krajska Nemocnice Liberec (I. Zykova); Nemocnice V Usti Nad Orlici (D. Prchal); St. Anne's University Hospital Brno (T. Bartosik); University Hospital Brno (M. Kolarova); University Hospital Olomouc (R. Hájek, J. Kohoutová, O. Marek); University Hospital Ostrava (P. Hon); University Hospital Plzen (I. Chytra); Denmark: Århus University Hospital (H. Betsch); Næstved Hospital (B. Fogh); Rigshospitalet (K. Espersen); Sygehus Fyn (K. Jacobsen); Vejle Sygehus (P. Berezowicz); Ecuador: Carlos Andrade Marín Hospital (F. Guerrero); Clinica La Merced (E. Salgado); Hospital Eugenio Espejo (D. Barahona); Hospital General de Las Fuerzas Armadas del Ecuador Hg-1 (H. Del pozo sanchez); Hospital Metropolitano (M. Jibaja); Egypt: Dar Alfouad Hospital (A. Alansary); Estonia: East Tallinn Central Hospital (A. Reintam); Tartu University Hospital (J. Starkopf); Finland: Helsinki University Central Hospital (V. Harjola); France: AP-HP, CHU Jean Verdier (L. Tual); Assistance Publique-Hôpitaux de Marseille, CHU Nord (M. Leone); Centre Hospitalier Dunkerque (M. Serge); Centre Hospitalier Universitaire (P. Michel); Centre Hospitalier (O. Leroy); Centre Hospitalier D'Auch (L. Mallet); Centre Hospitalier de Blois (B. Marc); Centre Hospitalier de Fougères (D. Dormoy); Centre Hospitalier de Niort (H. Pascal); Centre Hospitalier Dr Schaffner (L. Tronchon); Centre Hospitalier du Pays D'Aix (B. Garrigues); Centre Hospitalier Region Annecy (C. Santré); Centre Hospitalier Universitaire Amiens (H. Dupont); Centre Hospitalier Universitaire de Bicêtre (J. Duranteau); Centre Hospitalier Universitaire Reims (A. Leon); CH Colmar (L. Henry); CHG Armentieres (C. Canevet); CHU Angers (L. Dube); CHU Angers (H. Julien); CHU Bicetre (A. Nadia); CHU Brest (B. Francois); CHU de Bordeaux (J. Gérard); CHU Dijon
Hopital Général (M. Freysz); CHU Hôtel Dieu - APHP (G. Remy); CHU Nantes (Y. Blanloeil); Clinique Ambroise Paré (P. Squara); General Hospital (J. Korach); Grenoble University Hospital (M Durand); Groupe Hospitalier du Havre (C. Gabriel); Hia Laveran (P Eric); Hopital Antoine Béclère APHP (F. Jacobs); Hopital Bichat (R. Bronchard); Hôpital Claude Huriez, Centre Hospitalier Régional Universitaire de Lille (E. Kipnis); Hopital Cochin Paris (M. Moussa); Hôpital de Hautepierre (A. Launoy); Hopital de la Croix Rousse (C. Guérin); Hôpital Edouard Herriot (P. Vanhems); Hôpital Maison Blanche (A. Wynckel); Hôpital Raymond Poincaré (B. Clair); Hôpital Saint-Louis (E. Azoulay); Hôpital Tenon (J. Fulgencio); Hôpitaux Civils de Colmar (Y. Gottwalles); Hôpitaux Universitaires de Strasbourg (T. Krummel); Hospices Civils de Lyon (A. Lepape); La Rochelle Hospital (O. Lesieur); Lariboisiere University Hospital (D. Payen); Poissy Hospital (O. Hérvé); Polyclinique Saint André (J Farkas); Rangueil Hospital (P. Cougot); Réanimation Chirurgicale (Y. Malledant); University Hospital of Bordeaux Haut-Lèvéque (O. Joannes-Boyau); Germany: Academic Hospital Solingen (T. Standl); Ameos Klinikum St.Salvator Halberstadt GMBH (U. Sierig); Asklepios Fachkliniken München-Gauting (J. Geiseler); Asklepios Klinik Langen (H. Hopf); Behandlungszentrum Vogtareuth (M. Burgau); Bergmannsheil Bochum (E. Conrad-Opel); BethanienKrankenhaus (C. Hermann); Bundeswehrkrankenhaus Ulm (M. Ventzke); Charite/Campus Virchow-Klinikum (T. Henneberg); Charite Berlin-Buch (H. Loeser); Charité Campus, Mitte (C. Spies); Charité Campus, Virchow Klinikum (C. Spies); Charite Campus, Virchow (F. Esposito); Charité Universitätsmedizin Berlin (H. Zuckermann-becker); Clemenshospitl (R. Scherer); Dominikus Krankenhaus (A. Pauer); Drk-Kliniken Mark Brandenburg (S. Kljucar); Drk-Krankenhaus Ratzeburg (K. Delfs); Elisabeth-Krankenhaus Essen (E. Blank); Ev. Kliniken Bonn Betriebsstätte Waldkrankenhaus (J. Busch); Ev.-Freikirchliches Krankenhaus Rüdersdorf (K. Wendt); Evang. Krankenhaus Mülheim (J. Leßmann); Evangelische Kliniken Bonn Wadkrankenhaus (J. Busch); Evangelisches Krankenhaus Bielefeld (F. Bach); Friedrich Schiller University, Jena (Y. Sakr); Gemeinschaftskrankenhaus Herdecke (T. Berlet); Georg-August University of Göttingen (A. Kernchen); GeorgAugust-University of Göttingen (M. Quintel); Hanse-Klinikum Wismar (D. Holst); Heart clinic of the University of Munich (E. Kilger); Helfenstein Klinik (T. Holubarsch); Helios Klinik Lengerich (C. Raufhake); Helios-Klinikum Berlin-Buch (R. Kuhlen, C. Stolt); Helios Klinikum Emil Von Behring (A. Lubasch); Helios Klinikum Erfurt Gmbh (A. Meier-Hellmann); Helios Klinikum Wuppertal Barmen (G. Woebker); Henriettenstift (C. Scharnofske); Herz-Jesu-Krankenhaus (M. Breyer); Hochtaunus Kliniken Bad Homburg (T. Risch); Hospital Links Der Weser (C. Manhold); Icu In Drk Kliniken Mark Brandenburg (S. Kljucar); J.W. Goethe - University Medical School 
Frankfurt Am Main (D. Meininger); Johanniter Krankenhaus Bonn (C. Greive); Johanniter Krankenhaus Stendal Ggmbh (J. Rau); Jung-Stilling-Krankenhaus (A. Seibel); Katharinenhospital (A. Henn-beilharz); Katholisches Krankenhaus Hagen (R. Wolbert); Krankenhaus Prignitz Gemmeinnützige GMBH (T. Scherke); Klinik Am Eichert (J. Martin); Klinik Für Herzchirurgie (M. Rudolph); Klinik Füranästhesie, Operative Intensivmedizin U. Schmerztherapie (J. Gleißner); Kliniken Ludwigsburg-Bietigheim GMBH (M. Wolf); Kliniken Maria Hilf (F. Schleibach); Klinikum Augsburg (U. Jaschinski); Klinikum Bad Salzungen (A. Lunkeit); Klinikum Darmstadt (M. Welte); Klinikum Der J.W. Goethe-Universität (T. Bingold); Klinikum Der Stadt Wolfsburg (K. Sydow); Klinikum Emden (K. Kogelmann); Klinikum Forchheim (F. Fischer); Klinikum Fuerth (B. Fischer, M. Schmid); Klinikum Grosshadern, Universität München (M. Klein); Klinikum Harlaching Städtisches Klinikum Muenchen (A. Bechtold); Klinikum Hildesheim (K. Bodmann); Klinikum Kaufbeuren (J. Klasen); Klinikum Landsberg (H. Meyrl); Klinikum Lippe - Detmold (J. Goetz); Klinikum Ludwigsburg (G. Geldner); Klinikum Luedenscheid (T. Helmes); Klinikum Meiningen GMBH (N. Jensen); Klinikum Minden (H. Eickmeyer, W. Lengfelder); Klinikum Nürnberg (B. Langenstein); Klinikum Rechts Der Isar (R. Bogdanski); Klinikum Rechts Der Isar Der Technischen Universität München (S. Jelen-Esselborn, A. Umgelter); Klinikum Region Hannover (F. Dörr); Klinikum Region Hannover Krankenhaus Großburgwedel (K. Lütte); Klinikum Region Hannover, Krankenhaus Oststadt-Heidehaus (D. Heinemeyer); Klinikum Starnberg (M. Uhl); Klinikum Stuttgart - Olgahospital (P. Schirle); Klinikum Suedstadt (H. Benad); Klinikum Traunstein (M. Glaser); Klinikum Uelzen (W. Panzer); Klinikum Worms (E. Huettemann); Klinikverbund St. Ansgar, Krankenhaus Bassum (R. Stierwaldt); Klinikverbund Süd-West (M. Schappacher); Knappschaftskrankenhaus Bochum-Langendreer (E. Müller); Krankenhaus Freyung (Rural Hospital) (W. Stadlmeyer); Krankenhaus Lübbecke (M. Fantini); Krankenhaus Mol GMBH Strausberg (B. Dummer); Krankenhaus Nordwest (M. Thörner); Krankenhaus Nordwest (V. Jost); Krankenhaus Reinbek (T. Loerbroks); Kreisklinik Trostberg (T. Glück); Kreiskrankenhaus Bergstrasse (R. Zimmermann); Kreiskrankenhaus Calw (R. Clement); Kreiskrankenhaus Mechernich GMBH (R. Hering); Kreiskrankenhaus Nagold (T. Klinger); Kreiskrankenhaus Rottweil (J. Mehl); Kreiskrankenhaus St. Marienberg Helmstedt (H. Polozek); Leopoldina-Krankenhaus (A. Rothhammer); Ludmillenstift (R. Seidler); Lukas-Krankenhaus Bünde (P. Lorenz); Lungenfachklinik Amsee Waren Mueritz (M. Lutze); Marienhospital Bruehl (M. Euler); Marienkrankenhaus Schwerte (M. Heintz); Martin Luther Universität Halle (M. Winkler); Medizinische Klinik (M. Angstwurm); Mlu HalleWittenberg (K. Krohe); Mueritz-Klinikum Waren (T. Treu); Neurological Intensive Care Unit (T. Steiner); Oberschwaben- klinik Wangen (S. Locher); Orthopädische Klinik Markgröningen (A. Walz); Ostalb-Klinikum Aalen (P. Zahn); Otto-VonGuericke Universität Magdeburg (W. Brandt); Scivias-Krankenhaus St. Josef (M. Marks); Ska-Bileelfeld-Mitte (F. Henning); St. Antonius Hospital (U. Janssens); St. Hildegardis Krankenhaus Mainz (M. Luethgens); St. Johannes Krankenhaus (W. Theelen); St. Johannes-Hospital (M. Sydow); St. Johannes-Hospital (M. Weber); St. Josef-Hospital, Ruhr-Universität Bochum (A. Meiser); St. Josefs-Hospital (C. Deutschmann); St. Joseph Krankenhaus (C. Buttner); St.-Marien Hospital Lünen (M. Jokiel); St. Marienhospital Hamm (C. Bozzetti); St. Vincentius Kliniken (B. Jürgen); St.-Elisabeth Krankenhaus Köln-Hohenlind (F. Fiedler); St.-Vincentius-Krankenhaus Speyer (K. Wresch); Städtischen Kliniken Neuss - Lukaskrankenhaus (A. Kremer); Städtisches Klinikum Karlsruhe (H. Bleier); Städtisches Klinikum Wiesbaden, Dr.-Horst-Schmidt-Kliniken Hsk (M. Rueckert); Staedtisches Klinikum Guetersloh (H. Ditter); Staedtisches Klinikum Muenchen Gmbh - Klinikum Harlaching (C. Peckelsen); Staedtisches Klinikum Muenchen Gmbh/ Klinikum Bogenhausen (P. Friederich); Staedtisches Klinikum München - Klinikum Neuperlach (K. Weber); Tübingen University Hospital (W. Krueger); Ubbo-Emmius-Klinik Aurich (R. Lowack); Überlingen Hospital (A. Michalsen); Uniklinikum Dresden (M. Ragaller); Universitaetsklinikum des Saarlandes (A. Groeschel); Universitaetsklinikum Mannheim (T. Friedrich, U. Hoffmann); Universität Rostock (M. Hinz); Universitätsklinikum Der Martin-Luther-Universität Halle-Wittenberg (A. Christel); Universitätsklinikum Dresden Carl Gustav Carus (M. Ragaller); Universitätsklinikum Leipzig Aör (T. Hartwig); Universitätsmedizin Berlin Charité Campus Benjamin Franklin (S. Vögeler); University (M. Weiss); University Childrens Hospital Hauner (K. Reiter); University Hospital (T. Schwab); University Hospital Cologne (U. Trieschmann); University Hospital Dusseldorf (D. Kindgen-milles); University Hospital Giessen and Marburg Gmbh - Giessen (J. Engel); University Hospital Lübeck (B. Sedemund-adib); University Hospital Mainz (M. Lauterbach); University Hospital Marburg (M. Max); University Hospital Muenster (T. Volkert); University Hospital of Essen (C. Waydhas); University Hospital of Mannheim (S. Hien); University Hospital of Munich, LMU (J. Briegel); University Hospital of Regensburg (V. Guralnik); University Hospital Rwth Aachen (N. Zoremba); University Hospital Tübingen (R. Riessen); University Hospital Würzburg (W. Müllges); University Medical Center Hamburg-Eppendorf (A. Nierhaus); University of Erlangen (R. Strauss); University of Freiburg (S. Utzolino); University of Giessen (J. Thul); University of Greifswald (P. Abel, M. Gründling, W. Keßler); University of Heidelberg (K. Scheuren); University of Leipzig (E. Lothar, U. Kaisers, D. Schmitt, D. Schneider); University of Rostock (D. Vagts); University of Saarland (H. Rensing); University Hospital Essen (B. Schoch); Universty Hospital (K. 
Kopp); Vivantes - Klinikum Neukoelln (H. Gerlach); Vivantes Klinikum Prenzlauer Berg (M. Corea); Vivantes-Klinikum Am Urban (A. Uhrig); Westkuestenklinikum Heide (S. Schroeder); Westküstenklinikum Heide (F. Jordan); Westpfalz-Klinikum Kaiserslautern (T. Huber); Zentralöklinikum Augsburg (M. Bittinger) Greece: Ahepa University Hospital (E. Sofianos); Athens University Medical School (A. Armaganidis); Evangelismos Hospital (C. Routsi); G.Papanikolaou (M. Bitzani); General Hospital of Rethymno (A. Chalkiadaki); Henry Dunant Hospital (A. Michalopoulos); Hippokrateion Hospital Thessaloniki (E. Mouloudi); Kat General Hospital (E. Ioannidou); Kat Hospital (P. Myrianthefs); Kat Hospital, Athens (D. Koulenti); Konstantopoulio General Hospital (I. Karampela); Lamia General Hospital (G. Kyriazopoulos); Red Cross Hospital of Athens (K. Mandragos); Thriassio Hospital of Eleusis (P. Clouva-molyvdas); University Hospital of Ioannina (A. Moraiti); University Hospital of Alexandroupolis (I. Pneumatikos); University Hospital of Rion, Patras (K. Filos); University Hospital of Thessaly (Larissa) (E. Zakynthinos); University of Athens, Medical Shcool (A. Kotanidou); Xanthi General Hospital (A. Vakalos) Hong Kong: Northern District Hospital (A. Cheng); Princess Margaret Hospital and Yan Chai Hospital (T. Buckley); The Chinese University of Hong Kong (C. Gomersall) Hungary: National Institute of Neurosurgery (K. Kiss); Péterfy Hospital Budapest (P. Tamási); Saint George Hospital Hungary (A. Sarkany); Semmelweis University (A. Csomos); University of Szeged (É. Zöllei) India: Advanced Medicare Research Institute (S. Todi); B.D.Petit Parsee General Hospital (F. Udwadia); Bhailal Amin General Hospital (R. Shah); Bombay Hospital (P. Amin); Breach Candy Hospital Trust (F. Udwadia); Care Hospitals (S. Samavedam); Christian Medical College (A. Mathai); Cumballa Hill Hospital \& Heart Institute (M. Patil); Deenanath Mangeshkar Hospital (S. Jog); Dr. S. N. Medical College (M. Gurjar); Escorts Heart Institute \& Research Centre (M. Vats); Fortis Healthcare (A. Varma); Global Hospitals (P. Gopal); Hinduja Hospital \& Medical Research Center (F. Kapadia); Indraprastha Apoolo Hospitals (R. Chawla); Jehangir Hospital (S. Iyer); Kalinga Hospital (S. Sahu); Kasturba Hospital (C. Bakshi); Lokmanya Care Hospital (D. Ambike); Max Super Speciality Hospital (D. Govil); Medical Trust Hospital, Cochin (V. Karipparambath); Nh Hospital (J. Chacko); Ruby Hall Clinic (P. Sathe); Rungta Hospital (N. Rungta); Saifee Hospital (C. Jani); Seth Ramdas Shah Memorial Hospital \& Research Centre (A. Bhome); Shree Medical Foundation (S. Prayag); Sir Ganga Ram Hospital (S. Ray); Sundaram Medical Foundation (R. Rajagopalan); Tata Memorial Hospital (J. Divatia); Wockhardt Hospital (R. Da costa); Wockhrdt Hospital (T. Shyam Sunder) Indonesia: Bintaro International Hospital (P. Wibowo); Hasan Sadikin Hospital (T. Maskoen); Pantai Indah Kapuk Hospital (T. Sugiman) Islamic Republic of Iran: Imamreza Hospital (S. Nowruzinia); Laleh Hospital (A. Lotfi); Tehran University of
Medical Sciences (A. Mahmoodpoor) Ireland: Amnch (M. Donnelly); Cork University Hospital (D. Breen); Mater Misercordiae University Hospital (S. Ng); University Hospital Galway (J. Bates) Israel: Hadassah Medical Center (C. Sprung); Haemek Medical Center (A. Lev); Kaplan Medical Center (E. Kishinevsky); Rabin Medical Center (J. Cohen); Soroka Medical Center (S. Sofer) Italy: A.O Niguarda (S. Vesconi); A.O. Ospedale Di Circolo Di Busto Arsizio (S. Greco); A.O. TreviglioCaravaggio (M. Borelli); Anestesia E Rianimazione 2 Prof.De Gaudio (P. Cecilia); Arnas Ospedale Civico (M. Sapuppo); ASL 10 (A. Lazzero); ASL 10 Florence Hospital San Giovanni Di Dio (V. Mangani); Azienda Ospedaliera Desenzano (N. Petrucci); Azienda Ospedaliera Di Melegnano (M. Minerva); Azienda Ospedaliera G. Rummo (E. De blasio); Azienda Ospedaliera Polo Universitario San Paolo (S. Marzorati); Azienda Ospedaliera Santa Maria Alle Scotte (R. Rosi); Azienda Ospedaliera Universitaria P.Giaccone Policlinico (A. Giarratano); Azienda Ospedaliera-Universitaria Udine (O. Margarit); Azienda Ospedaliero -Universitaria (A. Guberti); Azienda OspedalieroUniversitaria S.M.Misericordia (S. Scolz); Clinica San Gaudenzio (E. Stelian); Fondazione IRCCS Policlinico San Matteo (V. Emmi); Fondazione Ospedale Maggiore Policlinico, Mangiagalli Regina Elena (M. Caspani); Fondazione Poliambulanza (A. Rosano); H San Gerardo (C. Abbruzzese); Hospital Panico Tricase (S. Colonna); Humanitas Gavazzeni (R. Ceriani); II Faculty of Medicne I University of Rome- Osp. S.Andrea (R. De Blasi); S. Salvatore Hospital (L. Panella); IRCCS Casa Sollievo Della Sofferenza (F. Borrelli); Istituto Nazionale Tumori Regina Elena (P. Lorella); KH Brixen (H. Ruatti); Osepdali Riuniti Di Ancona (C. Munch); Ospedale 'Ca Foncello' - Treviso (Italia) (C. Sorbara); Ospedale 'Santa Croce' - ASL 8 (G. Fiore); Ospedale Bufalini-Cesena (A. Chieregato); Ospedale Di Circolo E Fondazione Macchi (V. Conti); Ospedale Di Massa (A. Guadagnucci); Azienda USL Piacenza (M. Pizzamiglio); Ospedale Ferrarotto (M. Locicero); Ospedale Maggiore Ausl Bologna (I. Marri); Ospedale Maggiore Policlinico Milano (A. Sicignano); Ospedale Maggiore Policlinico, Mangiagalli E Regina Elena, IRCCS Milano (V. Conte); Ospedale Mugello Azienda Sanitaria Firenze (R. Oggioni); Ospedale Niguarda Ca Granda, Milano (A. De Gasperi); IRCCS Centro di Riferimento Oncologico della Basilicata (P. De Negri); Ospedale Provinciale Pistoia (G. Santagostino); Ospedale S. Gerardo (R. Fumagalli); Ospedale San Raffaele (G. Marino); Ospedele Vittorio Emanuele (G. Castiglione); P.O. San Severo Asl Fg (D. Sforza); S. Camillo Hospitql (N. Giuseppe); San Martino Hospital (M. Bassetti); Seconda Università Degli Studi Di Napoli (F. Ferraro); Sesto San Giovanni Hospital (S. Clementi); Teaching Hospital Careggi (D. Alessandro); Terapia Intensiva - Aso S. Giovanni Battista Di Torino - Ospedale Molinette (P. Cotogni, M. V. Ranieri); Università Cattolica (M. Antonelli); Universita' Cattolica Del S. Cuore (L. Martinelli); University-Hospital 
Careggi, Florence, (L. Gianesello); University Hospital Policlinico Di Catania (A. Gullo); University of Rome 'La Sapienza' (A. Morelli); UTI Trapianti (G. Biancofiore); University of Udine (G. Della Rocca) Japan: Kyoto Prefectural University of Medicine (S. Hashimoto); Nagoya University Hospital (M. Onodera); Oosaka-Fu Saiseikai Suita Hospital (A. Kobayashi); Sanai Hospital (T. Shinozuka); Tokushima University School of Medicine (H. Imanaka); Tokyo Medical University, Hachioji Medical Center (T. Ikeda); Tokyo Women's Medical University (A. Yaguchi) Latvia: Hospital of Traumatology and Orthopedics (I. Misane); 7th Hospital of Riga (A. Piebalga) Lebanon: Lebanese Canadian Hospital (A. Moughaghab) Lithuania: Medicine University of Kaunas (V. Pilvinis); Vilnius University Emergency Hospital (S. Vosylius); Vilnius University Hospital Santariskiu Clinics (M. Balciunas, G. Kekstas) Luxembourg: Centre Hospitalier de Luxembourg (H. Margaret); Clinique Ste Thérèse (M. Klop) Macedonia: Clinic For Infectious Diseases (K. Grozdanovski); General Hospital Stip (B. Eftimova) Malaysia: Faculty of Medicine, Universiti Kebangsaan Malaysia (S. Wafa); Hospital Pulau Pinang (C. Lim); Hospital Tengku Ampuan Afzan, Kuantan, Pahang (M. Mat nor); Kuala Lumpur Hospital (L. Tai); National Heart Institute (S. Syed Mohd Tahir); Sarawak General Hospital (N. Idris); Sultanah Aminah Hospital (C. Tan) Malta: St Luke's Hospital (M. Borg); Mexico: Angeles Metropolitano Hospital (E. Manzo); Centro Medico Lic.Adolfo Lopez Mateos (H. Gutierrez Morales); Hgr 25 Imss Zaragoza (P. Miguel); Hospital Angeles Clinica Londres (A. Villagomez); Hospital Angeles del Carmen (A. Bassols); Hospital Civil de Guadalajara 'Fray Antonio Alcalde' (G. Aguirre); Hospital Español de México (U. Cerón); Hospital General Bernardo J. Gastelum (J. Lopez ramos); Hospital General del Estado ‘Dr Ernesto Ramos Bours', Hermosillo Sonora Mexico (J. Monjardín); Hospital General Regional de Leon (E. Bermudez Aceves); Hospital General Reynosa (F. Gonzalez Salazar); Hospital Juan I.Menchaca Hospital Civil de Guadalajara (D. Rodriguez Gonzalez); Hospital Juárez de México (M. Poblano-Morales); Hospital Mèdica Sur (F. Ramirez); Hospital O'horan (M. Cetina); Hospital Privado de Hermosillo (J. Navarro); Hospital Regional 1 Octubre, Issste (A. Villagomez Ortiz); Hospital San Jose Tec Monterrey (V. Sanchez); Hospital Universitario 'Dr. Jose E. Gonzalez' (U. Chavarria); IMSS (O. Fernandez-Ponce); Iner (H. Serna secundino); Instituto de Salud del Estado de Aguascalientes (O. Leonardo); Instituto Mexicano del Seguro Social (R. Diego Manuel, J. Mijangos); Issemym Medical Center (G. Vazquez de Anda); Mexican Red Cross (E. Martin); Ocq Hospital (P. Gutierrez); Secretaria de Salud del Gobierno del Distrito Federal (I. López Islas); Servicios de Salud En Yucatan (L. Soberanes) Montenegro: Clinical Center of Montenegro (P. Ljubica) Morocco: Chu Ibn Sina (A. Sbihi); Polyclinique CNSS Derb Ghallef (B. Ouahid); Réanimation Médicale, Hôpital Ibn Sina (M. Naoufel) Netherlands: Academic Medical Center (A.
De Pont); Amphia Hospital (P. Rosseel); Antoni Van Leeuwenhoek Ziekenhuis (J. Ten Cate); Beatrix Zienhuis Rivas Zorggroep (G. Van Berkel); Canisius Wilhelmina Ziekenhuis (S. Corsten); Erasmus Mc University Medical Center (J. Bakker); Hagaziekenhuis (J. Vogelaar); Hofpoort Hospital Woerden (H. Blom); Isala Clinics (H. Kieft); Medical Center Leeuwarden (M. Kuiper); Medisch Spectrum Twente (A. Gille); Radboud University Nijmegen Medical Centre (P. Pickkers); Rode Kruis Ziekenhuis (J. Vet); Slingeland Ziekenhuis (J. Ammann); Spaarneziekenhuis (S. Den Boer); St. Antonius Ziekenhuis (R. Wesselink); St.Elisabeth Hospital (B. Speelberg); Twenteborg Hospital Almelo (C. Pham); University Medical Center, Groningen (M. Rodgers); University Hospital Maastricht (D. Bergmans); Vu University Medical Center (J. Groeneveld) New Zealand: Auckland City Hospital (C. Mcarthur); Auckland City Hospital (R. Parke); Christchurch (J. Mehrtens); Dunedin Hospital (L. Celi); Hawkes Bay Hospital (R. Freebairn); Middlemore Hospital (N. Rankin); Nelson Marlborough District Health Board (C. Heffernan); Palmerston North Hospital (G. McHugh); Starship Children's Hospital (J. Beca); Waikato Hospital (F. Van haren); Wellington Public Hospital (B. Barry); Whangarei Base Hospital (M. Kalkoff) Norway: Aker University Hospital (R. Loevstad); St Olavs University Hospital (P. Klepstad); Sykehuset Asker Og Bærum Hf (P. Erno); Sykehuset I Vestfold Hf , Toensberg (A. Junker) Pakistan: Armed Forces Institute of Cardiology (S. Naqvi); Jinnah Hospital Lahore Pakistan (I. Javed) Panama: Complejo Hospitalario Metropolitano (J. Sinclair) Peru: Hipolito Unanue Hospital (R. Rivera); Hospital Regional Honorio Delgado (C. Chavez); Hospital Alberto Sabogal Sologuren (Z. Donayre Taber); Hospital Dos De Mayo (R. Quispe Sierra); Hospital Edgardo Rebagliati Martins (J. Muñoz); Hospital Maria Auxiliadora (J. Galvez Ruiz); Hospital Nacional Almanzor Aguinaga Asenjo Essalud Chiclayo (J. Fang Li); Hospital Nacional Arzobispo Loayza (M. Candiotti Herrera); Hospital Víctor Lazarte Echegaray (A. Arroyo); Instituto de Salud del Niño (R. Becerra); Navy Hospital (J. Meza); Peruvian Air Force Central Hospital (M. Mayorga) Poland: 4th Military Clinical Hospital (P. Garba); Academic Centre for Maritime and Tropical Medicine AMG (J. Kot); Barlicki University Hospital, University of Medical Science, Lodz, (T. Gaszynski); Boleslaw Szarecki Teaching Hospital No. 5 of The Medical University In Lodz (M. Piechota); Clinical Hospital No 2 (S. Renata); Collegium Medicum Jagiellonian University (P. Müller); Institute of Cardiology (J. Stepinska); J. Brudzinski's Hospital In Gdynia (K. Jacek); Jagiellonian University (T. Cieniawa); Karol Marcinkowski University of Medical Sciences (A. Mikstacki, B. Tamowicz); Poznan University of Medical Sciences (A. Bartkowska-Sniatkowska); Silesian University of Medicine (E. Karpel); University Hospital Bydgoszcz Cm Umk (K. Kusza); University Hospital No 2 (P. Smuszkiewicz); University 
Hospital Warsaw (M. Mikaszewska-Sokolewicz); Wojewodzki Szpital Specjalistyczny (R. Goraj); Wroclaw Medical University (A. Kubler) Portugal: Centro Hospitalar Alto Ave (A. Bártolo); Centro Hospitalar Cova Da Beira (M. Castelo-Branco Sousa); Centro Hospitalar Trás os Montes e Alto Douro (F. Esteves); CHLO-Hospital S Francisco Xavier (A. Martins); H S João (T. Oliveira); Hospital CUF Infante Santo (P. Ponce); Hospital Curry Cabral (L. Mourão); Hospital da Luz (C. Febra); Hospital de Egas Moniz (E. Carmo); Hospital de S. José (V. Lopes); Hospital de São Francisco Xavier (P. Póvoa); Hospital de São José (A. Rezende); Hospital Divino Espirito Santo (H. Costa); Hospital do Litoral Alentejano (P. Moreira); Hospital Dr. José Maria Grande, Portalegre (F. Pádua); Hospital Fernando Fonseca (A. Leite); Hospital Garcia de Orta (E. Almeida); Hospital Geral de Santo António (M. Alves); Hospital de Pulido Valente (A. Sousa, L. Telo); Hospital de S. João (C. Dias, J. Paiva); Hospital de São Bernardo (R. Ribeiro); Hospital de São Sebastião, EPE (P. Amaro); Hospital Geral de Sto Antánio (A. Carneiro); Hospital de St. António dos Capuchos (R. Moreno, Ricardo Matos, Susana Afonso); Instituto Português de Oncologia de Lisboa (M. Bouw); Hospital de St Maria (C. França) Qatar: Alkhor Hospital (A. Ibrahim); Romania: 'Maria

Sklodowska Curie' Children's Emergency Hospital, Bucharest (R. Tabacaru); Department Public Hospital (V. Ionita); Fundeni Institute (D. Tulbure); Institute of Cardiovascular Disease (D. Filipescu); Institutul de Boli Cardiovasculare Si Transplant Tg. Mures (S. Pascanu); Spitalul 'Sf. Spiridon' (I. Grigoras); University Emergency County Hospital (S. Copotoiu) Russia: Bakoulev Scientific Center For Cardiovascular Surgery (D. Popov); City Clinical Hospital (E. Lebedev); City Hospital (I. Olga); City Hospital \#7 (A. Yaroshetskiy); Clinical Hospital N 40 (T. Lugovkina); Ekaterinburg. University Hospital N 40 (B. Dmitry); Izhevsk State Medical Academy (O. Malinin); Moscow Children's Surgery Institut (A. Lekmanov) Saudi Arabia: Alawi Tunsi Hospital (M. Abulmagd); King Abdulaziz Medical City (Y. Arabi); King Abdulaziz University Hospital (J. Alhashemi); King Fahad Specialist Hospital Dammam (A. Ali); King Faisal Specialist Hospital (K. Maghrabi); Kingdom Hospital (A. Debek); Riyadh Millitary Hospital (M. Malik) Serbia: Clinical Center Nis (R. Jankovic); Clinical Centre of Serbia (I. Palibrk); Dedinje Cardiovascular Institute (V. Maravic-stojkovic); KBC Bezanijka Kosa (V. Malenkovic); Military Medical Academy, Belgrade (M. Surbatovic); University of Belgrade (V. Bumbasirevic) Singapore: Changi General Hospital (N. Lim); Kk Hospital (T. Loh); Tan Tock Seng Hospital (H. Tan) Slovakia: Fakultna Nemocnica Nitra (H. Sekeresova); FNSP Bratislava-Hospital Ruzinov (J. Koutun); Madical Faculty Hospital Kosice (J. Firment); Nusch Bratislava (P Malik); Reiman Hospital (S. Trenkler) Slovenia: Clinic Center Ljubljana (I. Muzlovic); General Hospital Novo Mesto (L. Kosec, B Ozek); General Hospital Slovenj Gradec (D. Kasnik); University Clinic of Respiratory and Allergic Diseases (V. Tomic); University Clinical Center Ljubljana (R. Knafelj); University Medical Center Ljubljana (V. Svigelj) South Africa: 1 Military Hospital (H. Du Plessis); Groote Schuur Hospital (R. Raine); Johannesburg Hospital (S. Bhagwanjee, G. Richards, J. Scribante); Johannesburg Hospital Trauma Unit (J. Goosen); Unitas Hospital (J. De Jager); Wits Donald Gordon Medical Center (G. Schleicher) Spain: Althaia (O. Rubio); Bellvitge University Hospital (R. Mañez); Centro Medico Delfos (M. Burgueño Campiñez); Clinica Moncloa (M. Alvarez); Clinica Rotger (R. Jorda); Clinica Santa Elena (E. Naveira-Abeigón); Clinica Universitaria de Navarra (P. Monedero); Complejo Hospitalario de Pontevedra (E. Alemparte-Pardavila); Fundacion Hospital Alcorcon (S. Garcia del Valle); Fundacion Jimenez Diaz (C. Perez Calvo); H Vall Hebron (M. Palomar); H.U. Virgen de Las Nieves- H. Traumatología Y Rehabilitación (F. Guerrero); Hospital 'Virgen de La Concha' - Zamora (A. Caballero Zirena); Hospital Arnau de Vilanova (M. Arribas); Hospital Can Misses (E. Bustamante Munguira); Hospital Casa de Salud (J. Ruiz); Hospital Central de Asturias (L. Iglesias); Hospital Clinic (E. Zavala); Hospital Clinic de Barcelona (M. Valencia); Hospital Clinico San Carlos (A. Blesa Malpica); Hospital Clinico San Carlos (F. Martinez-Sagasti, M. Nieto); Hospital Clinico Universitario (G. Aguilar); Hospital Clinico Universitario de Santiago (F. Martinon-Torres); Hospital Comarcal Vinaros (C. Lorente); Hospital de Navarra (J. Insausti); Hospital de Antequera (R. Vegas Pinto); Hospital de Basurto (I. Santos); Hospital de Fuenlabrada (A. Escriba); Hospital de Galdakao (P. Olaechea); Hospital de La Merced (E. Muñoz); Hospital de Manacor (E. Antón Caraballo); Hospital de Mostoles (P. Galdos-Anuncibay); Hospital de Sagunto (V. Lopez Camps); Hospital de Tortosa Verge de La Cinta (F. Esteban-Reboll); Hospital del Sas de Jerez (A. Estella); Hospital Donostia (L. Bocero); Hospital Dr Peset (A. Ibañez); Hospital G. Yagüe (L. Pueyo); Hospital General (L. María Jesús); Hospital General de Asturias (L. Iglesias); Hospital General de Ciudad Real (J. Silva); Hospital General de Granollers (P. Garro); Hospital General de La Palma (L. Ramos-gómez); Hospital General de L'Hospitalet (A. Rovira); Hospital General de Vic (M. Martin Delgado); Hospital General Salud 'Obispo Polanco' (J. Monton Dito); Hospital General Universitario de Albacete (F. Garcia); Hospital General Universitario de Alicante (J. Navarro); Hospital General Universitario de Elche (J. Latour-Perez); Hospital General Universitario de Guadalajara (A. Albaya); Hospital General Universitario Gregorio Marañon (A. Bustinza); Hospital Gran Canaria ‘Dr Negrín' (J. Sole-violán); Hospital Marques de Valdecilla (P. Ugarte Peña); Hospital Maz (I. Yuste); Hospital Parque San Antonio (J. De Rojas Román); Hospital Sabadell (J. Vallés); Hospital Sant Joan de Déu (E. Esteban); Hospital Sant Pau (E. Quintana Tort-Martorell); Hospital Santa María del Rosell (M. 
Moreno); Hospital Santa Maria Madre-Complejo Hospitalario de Ourense (V. López Ciudad); Hospital Santiago Apostol (A. Manzano Ramirez); Hospital Sevilla-Aljarafe (J. Sánchez-Olmedo); Hospital Son Llàtzer (M. Borges); Hospital Terrassa (J. Amador Amerigo); Hospital Torrecardenas (F. Guerrero Gomez); Hospital Universitaio 12 de Octubre (J. Montejo González); Hospital Universitari de Girona Doctor Josep Trueta (J. Sirvent); Hospital Universitari Germans Trias I Pujol (E. Mesalles Sanjuan); Hospital Universitario Arnau de Vilanova (F. Barcenilla-Gaite); Hospital Universitario de Canarias (N. Serrano); Hospital Universitario de Getafe (E. Cerdá); Hospital Universitario de Valme (A. Lesmes Serrano); Hospital Universitario Doce de Octubre (C. Garcia-Fuentes); Hospital Universitario Infanta Crsitina (J. Macias Pingarrón); Hospital Universitario $\mathrm{N}^{\mathrm{a}}$ sra de Candelaria (E. Espinosa); Hospital Universitario Principe de Asturias (M. Sanchez Garcia); Hospital Universitario Reina Sofía, Murcia (F. Felices); Hospital Universitario Virgen de La Victoria (M. de la Torre-Prados); Hospital Univesitario Puerto Real (H. Maria Jesus); Hospital Valle del Nalon (V. Luis); Hospital Virgen Arrixaca (R. Jara); Hospital Xanit Internacional (M. Briones Lopez); Hospital Xeral Cies (P. Posada); Hu La Paz (B. Galvan); Hu La Paz (F. Mariscal); Joan Xxiii University Hospital (J. Rello); Morales Meseguer (B. Gil); Puerta del Mar Universitary Hospital (R. Sierra); Rio Hortega University Hospital (J. Rico-Feijoo); San Pedro de Alcantara Hospital (C. Corcobado Márquez); Servicio Navarro de Salud.Hospital Virgen del Camino (J. Izura); Uci H. U. Salamanca (J. González); Universitary Hospital Dr. Peset (J. Soto Ibánez) Sudan: Soba University Hospital (H. Agabani) Sweden: Anestesikliniken (P. Petersen); Centralsjukhuset Karlstad (L. Johansson); University Hospital, Linköping ( $\mathrm{H}$. Blomqvist, B. Peterzén, N. Wyon); Göteborg (I. Lindström); Kärnsjukhuset Skövde (A. Paulsson); Karolinska University Hospital Huddinge (C. Agvald-Ohman); Karolinska University Hospital, Solna (J. Petersson); Lund University Hospital (H. Friberg); Malmoe University Hospital (V. Einar); Op/ Iva Kliniken (F. Hammarskjöld); Ostersund Hospital (M. Schindele); Ostra Hospital, Göteborg (S. Arvidsson); Sahlgrenska University Hospital (J. Sellgren); Söder Hospital (Södersjukhuset) (J. Hulting); Sodersjukhuset (J. Häggqvist); Sollefteå Hospital (J. Rudenstam); Sunderby Hospital (D. Lind); The Queen Silvia Children's Hospital (E. Kokinsky); Thoracic Intensive Care, Karolinska Hospital (A. Owall); Umeå University Hospital (S. Jacobson); University Hospital (H. Stiernstrom); University Hospital of Örebro (A. Nydahl) Switzerland: CHUV, Lausanne (P. Eggimann); University of Geneva (R. Stocker); Hirslanden Klinik Beau-Site (G. Loderer); Kantonsspital Liestal (R. Loetscher); Kantonsspital Luzern (A. Mehlig); Lindenhofspital (K. Heer); Neuchâtel (H. Zender); Ospedale Civico Di Lugano (S. Cottini); Regional Hospital Mendrisio (A. Pagnamenta); Stadtspital Triemli (G. Eich); Swiss
Paraplegic Centre (P. Felleiter); University Hospital Zurich (M. Maggiorini); University Hospitals of Geneva (J. Pugin) Taiwan: Changhua Christian Hospital (W. Shu-Hui); Kaohsiung Veterans General Hospital (K. Hsieh) Thailand: Faculty of Medicine Siriraj Hospital (P. Toomtong); Prince of Songkla University (B. Khwannimit); The Bnh Hospital (P. Kietdumrongwong) Tunisia: Children's Hospital of Tunis (A. Khaldi); Hopital Aziza Othmana (A. Messadi); Military Hospital of Tunis (I. Labbene); Mongi Slim Hospital (N. Frikha) Turkey: Acibadem Kadikoy Hospital (K. Atalan); Acibadem Bakirkoy Hospital (C. Ates); Acibadem Bursa Hospital (A. Kahveci); Acibadem Kozyatagi Hospital (H. Fistikci); Ankara Univercity (A. Kaya); Ankara University Medical Faculty, Ibni Sina Hospital (E. Ozgencil); Ataturk University Medical Faculty (M. Kizilkaya); Dicle University Medical School (M. Bosnak); Dokuz Eylul University (H. Bodur); Dokuz Eylul University School of Medicine (M. Akan); Erciyes University Medical Faculty (M. Guven); Gazi University School of Medicine (M. Turkoglu); Hacettepe University Hospital (A. Topeli); Inonu University Medical Faculty (T. Togal); Istanbul Faculty of Medicine (N. Uzel); Istanbul Medical Faculty (I. Akinci, N. Cakar, S. Tugrul); Istanbul University Cerrahpasa Medical School (O. Demirkiran); Izmir Ataturk Training and Resarch Hospital (T. Adanir); Memorial Hospital (K. Dogruer); Okmeydani Teaching \& Research Hospital (A. Turkmen); Okmeydani Teaching \& Research Hospital (H. Guven); Ondokuz Mayis University, Medical Faculty (F. Ulger); Selcuk University Meram Faculty of Medicine (S. Kocak) Ukraine: Lugansk City Hospital No. 7 (Y. Nalapko); Lugansk District Hospital (Y. Nalapko) United Arab Emirates: Al-Mafraq Hospital (S. Rady); Department of Health \& Medical Services (A. Alsabbah); Dohms (N. Elahi); Dubai Hospital (H. Al rahma); Tawam Hospital (M. Rahman, S. Kashef) United Kingdom: Aberdeen Royal Infirmary (B. Cuthbertson); Addenbrookes Hospital (K. Gunning); Barnsley Hospital (Y. Myint); Bristol Royal Infirmary (J. Bewley); Cambridge University Teaching Hospitals (R. Burnstein); Christie Hospital (P. Haji-Michael); Dumfries and Galloway Royal Infirmary (D. Wrathall); Kent and Canterbury Hospital (L. Folan); Freeman Hospital (I. Nesbitt); Friarage Hospital Northallerton (A. Ratnaparkhi); Frimley Park Hospital (S. Pambakian); Glasgow Royal Infirmary (M. Booth); Great Western Hospital Swindon (M. Watters); Guys and St Thomas' NHS Foundation Trust (T. Sherry); Huddersfield Royal Infirmary (U. Buehner); Hurstwood Park Neurosurgical Centre (C. Barrera Groba); James Paget University Hospital (P. Bothma); John Radcliffe Hospital (N. George, J. Millo; Kettering General Hospital (L. Hollos); Lothian University Hospitals Trust (S. Mclellan); Macclesfield District General Hospital (J. Hunter); Manchester Royal Infirmary (M. Garrioch, N. O'Keeffe); Medway NHS Trust (N. Divekar); Morriston Hospital (S. Eggert); New Cross 
Hospital,Wolverhampton; (S. Smith); Newcastle General Hospital (A. Vincent); Newham University Hospital Trust (P. Withington); NHS Tayside (C. Macmillan); Northampton General Hospital (R. Webster); Papworth Hospital (A. Vuylsteke); Peterborough Hospitals (B. Appadu); Princess Royal Hospital (C. Barrera groba); Queen Alexandra Hospital, Portsmouth (P. McQuillan); Queen Elizabeth Hospital (M. Blunt); Queen Elizabeth Medical Center, Birmingham (N. Parekh); Rotherham DGH (D. William); Royal Berkshire Hospital (C. Jones); Royal Blackburn Hospital (A. Krige); Royal Bournemouth NHS Foundation Trust (M. Schuster-Bruce); Royal Cornwall Hospital (J. Boyden); Royal Devon \& Exeter NHS Foundation Trust (C. Boulanger); Royal Infirmary of Edinburgh (D. Swann); Royal Liverpool University Hospital (J. Walker); Royal Marsden Hospital (T. Wigmore); Royal Shrewsbury Hospital (R. Law); Royal Sussex County Hospital (F. Baldwin); South Tyneside Hospital (C. Muench); Southmead Hospital (S. Robinson); St George's Hospital (A. Crerar-Gilbert, A Rhodes); St Helens and Knowsley Hospital (T. Mahambrey); St John's Hospital (L. Cameron); St. James's University Hospital (J. Thornton); St. Mary's Hospital (M. Stotz); St. Peters Hospital (M. Russell); Stirling Royal Infirmary (A. Longmate); Tameside General Hospital (R. Kitson); Taunton \& Somerset NHS Trust (B. Browne); The Hillingdon Hospital (A. Thorniley); The James Cook University Hospital (I. Gonzalez); Torbay Hospital (M. Swart); University College Hospital (M. Singer); University Hospital Birmingham (N. Gautam); University Hospital of South Manchester (V. Prasad); University Hospitals Coventry \& Warwickshire Nhs Trust (D. Watson); West Middlesex University Hospital (T. Szakmany); West Suffolk Hospital (J. Cardy); Western Infirmary Glasgow (A. Binning); Wexham Park Hospital (R. Loveland); Wirral Hospitals Nhs Trust (J. Gannon); Wolverhampton Hospital (G. Martinelli); Wythenshawe Hospital (P. Nightingale); Yeovil District Hospital (J. Howes) United States: Baystate Medical Center (J. Steingrub); Denver Health Medical Center (L. Ammons); Emory University Hospital - MICU (M. Fisher); Englewood Hospital Medical Center (N. Gandhi); Grady Memorial Hospital-Emory University (G. Martin); Hospital of The University of Pennsylvania (C. Deutschman); LDS Hospital, Salt Lake City (N. Dean); Inova Fairfax Hospital (C. Michetti); Los Angeles
County+University of Southern California Medical Center $(\mathrm{H}$. Belzberg); LSUHSC Shreveport (K. Hutchinson); Maine Medical Center (T. Van der kloot); Mayo Clinic (B. Afessa); Mount Sinai School of Medicine (D. Kaufman); Nassau University Medical Center (J. Iqbal); New York University (D. Ost); Northwestern University (M. West, R. Wunderink); Northwestern University Feinberg School of Medicine Critical Care (S. Afifi); Olive View Ucla Medical Center (S. Stein); Oregon Health \& Science University (D. Hagg); Orlando Regional Medical Center (E. Jimenez); Penn State Hershey Medical Center (S. Blosser); Rochester General Hospital (S. Chhangani); Rush University Medical Center (R. Kleinpell); Rutland Regional Medical Center (H. Reich); Scott and White Hospital (E. Fileds); Sharp Memorial Hospital (D. Willms); South Texas Veterans Health Care System (P. Castellanos-Mateus); St. Joseph Medical Center Fhs (L. Melnik); Texas Tech University Health Sciences Center (L. Oud); Cardiovascular ICU, The Methodist Hospital, Houston (E. Chi, Y. Brown); Medical ICU, The Methodist Hospital, Houston (R. Halfon); The University of Mississippi Medical Center (A. Badr); The University of Texas Health Science Center at San Antonio (M. Restrepo, P. Castellanos-Mateus); University of Chicago (A. Pohlman); University of Cincinnati (R. Branson); University of Kansas Hospital (S. Simpson); University of Miami School of Medicine (D. Kett); University of Michigan (T. Jacobs, P. Park, W. Wahl); University of Texas Health Science Center at San Antonio (C. Patricia); University of Toledo Medical Center (J. Hammersley, T. Papadimos); University of Virginia (R. Sawyer); Uthsc At Memphis - Regional Medical Center (Site) (A. Freire); Veterans Caribbean Healthcare System (W. Rodriguez); Washington Hospital Center (A. Ryan); West Suburban Medical Center (B. Margolis); Winthrop University Hospital (M. Groth) Uruguay: Amecom (H. Escanda); Comta (J. Baraibar); Hopital Policial (D. Paciel); Hospital Maciel (H. Bagnulo); Hospital Tacuarembo (F. Hitta); Médica Uruguaya Corporación de Asistencia Médica (P. Nadales); Sanatorio Americano - Femi (H. Albornoz) Venezuela: Hospital Dr Luis Ortega (Z. Salmen); Hospital Unversitario de Caracas (C. Pacheco) Vietnam: Bach Mai Hospital (T. Bui); Franco Vietnamese Hospital (F. Potie); Ninh Thuan Hospital (C. Nguyen Huu). 